\title{
Synchronized nutrient stress conditions trigger the diversion of CDP-DG pathway of phospholipids synthesis towards de novo TAG synthesis in oleaginous yeast escalating biodiesel production
}

\author{
Alok Patel, Vikas Pruthi, Parul A. Pruthi* \\ Molecular Microbiology Laboratory, Department of Biotechnology, Indian Institute of Technology Roorkee (IIT-R), Roorkee, Uttarakhand, 247667, India
}

\section{A R T I C L E I N F O}

\section{Article history:}

Received 28 February 2016

Received in revised form

4 July 2017

Accepted 12 August 2017

Available online 13 August 2017

\section{Keywords:}

Oleaginous yeast

Lipid accumulation

Fatty acid methyl esters

Biodiesel properties

\begin{abstract}
A B S T R A C T
In this study oleaginous yeast, Rhodosporidium kratochvilovae HIMPA1 grown in glucose synthetic medium containing different nitrogen $(1 \mathrm{~g} / \mathrm{l}$ and $0.1 \mathrm{~g} / \mathrm{l})$ and phosphorus $(0.05 \mathrm{~g} / \mathrm{l}$ and $0.1 \mathrm{~g} / \mathrm{l})$ limited conditions. Among various $\mathrm{N}$ and P-limited conditions, the highest lipid content $(60.34 \pm 0.69 \%)$ obtained under synchronized limitation of $\mathrm{N}$ and $\mathrm{P}(0.1 \mathrm{~g} / \mathrm{l} \mathrm{N}$ and $0.05 \mathrm{~g} / \mathrm{l} \mathrm{P})$. Live fluorescent cell imaging of yeast cells after BODIPY ${ }_{505-515} \mathrm{~nm}$ staining endorses the results of triacylglycerol (TAG) accumulation in lipid droplets. The cells grown in synchronized limitation of $\mathrm{N}$ and $\mathrm{P}$ exhibited boosted cell size $(6.76 \pm 0.39 \mu \mathrm{m})$ and lipid droplet size $(5.62 \pm 0.28 \mu \mathrm{m})$. Under synchronized limitation of $\mathrm{N}$ and $\mathrm{P}$, supersized irregular shaped lipid droplets (LD) coalesced to form big lobules in the cellular compartment of oleaginous yeast having $87.14 \%$ enhanced TAG accumulation as depicted by TLC. Synchronized nutrient limitation diverts the CDP-DG pathway of phospholipids synthesis towards de novo TAG synthesis. The maximum increment of oleic acid (C18:1) was reported in synchronized limitation of $\mathrm{N}$ and $\mathrm{P}$ that improve the biodiesel properties like oxidative stability, viscosity, cetane number and cold filter plugging point.
\end{abstract}

() 2017 Elsevier Ltd. All rights reserved.

\section{Introduction}

World research scenario has been focused on sustainable biofuel production due to hike in fossil fuel prices and critical environmental disputes on climate change [1]. Biodiesel is emerging as a major alternative to fossil fuels [2]. Its renewable, sustainable and eco-friendly nature make it a perfect vehicular fuel for polluted metro cities [3]. Production of biodiesel is totally reliant on the availability of triacylglycerol feedstocks such as vegetable oils (edible or non-edible), waste cooking oils and animal fats [4]. Its production from oils obtained from vegetable and food sources are no more sustainable and economical due to universal food securities reasons and it is necessary to search for novel resources to produce biodiesel. Microbial oils obtained from yeasts, bacteria, fungi, and algae could be a technologically feasible choice for biodiesel production as they have higher lipid yield under controlled environmental conditions than the plants and can be easily scaled up [5-7]. Only a minor population of yeasts are known to

\footnotetext{
* Corresponding author

E-mail address: parulaggarwalpruthi@gmail.com (P.A. Pruthi).
}

synthesize more than $20 \%$ of total lipid in its cellular compartment in the form of lipid droplets (LDs) after exploiting organic carbon sources [8]. Rhodosporidium, Rhodotorula, Yarrowia, Cryptococcus, Candida, Lipomyces and Trichosporon are some of the oleagenic yeast genera which accumulate more than $65 \%$ of lipid in their cellular compartment. Among these oleaginous yeast genera, Rhodosporidium has been recorded to produce the highest amount of lipid (67.5\%) in its cellular compartment [6]. Oleaginous yeast has the unique property to grow well and utilize a large number of waste products from industries and agricultural residues for the synthesis of storage lipids (triacylglycerols) in its cellular compartment $[1,9,10]$.

Industrial production of biodiesel still faces hurdles as it is totally dependent on the feedstock used and down streaming of the fermentation process. The high costs associated with the biodiesel production are mainly due to the cost of raw materials and their fuel conversion routes. The cost of raw material imparts $60-80 \%$ of the total cost of biodiesel production, however, it can be reduced if glucose based renewable substrates (sugarcane bagasse or waste products) are used as carbon source [11]. In order to reduce the overall production cost, an alternative to conventional solvent 
extraction process is in situ transesterification where the conversion of oil into fatty methyl esters (FAME) is directly obtained from the wet biomass [12]. However, Ratledge and Cohen (2008) suggested that microbial oil is not yet a promising alternative for 2 nd generation biodiesel production due to high production cost than the biodiesel obtained from vegetable sources. Even the disposability of de-oiled biomass generates several problems [13]. Although, it may be feasible later in 10-15 years when the price of vegetable oil will be too high than that of microbial oil, which will have a positive realistic market opportunity [13]. On the other hand, during previous decades there is huge expansion of interest in producing SCO amenable for biodiesel synthesis (a process that, as stated previously, yet is not economically competitive), due to the interest in the microorganisms producing essential lipids that are rarely found in the plant or animal kingdom [i.e. lipids containing rare polyunsaturated fatty acids (PUFAs) or cocoa-butter equivalents]. An alternative cost effective approach to the microbial oil for biodiesel production is to produce medically and dietetically important polyunsaturated fatty acids (PUFA) such as $\gamma$ linolenic, dihomo- $\gamma$-linolenic, arachidonic, and eicosapentaenoic acid [14-17]. Contrary to these assumptions, the recent scenario of biodiesel production witness cost effective pilot-scale biodiesel production of Rhodosporidium toruloides DEBB 5533 using a lowcost medium composed of sugarcane juice and urea (1000 l working volume). It was shown that the overall biodiesel production cost was economically competitive (US\$ $0.76 / 1$ ) to that of vegetable biodiesel (US\$ 0.81/1) and the yield of biodiesel is 6.3-fold higher (4172 1/ha of cultivated sugarcane) than that obtained from yield of soybean biodiesel ( $661 \mathrm{l} /$ ha of cultivated soybean) [18]. The nature of fatty acids synthesized by oleaginous yeast relies on the nutritional content of the provided medium and culture conditions $[19,20]$. There are several new strategies already known to improve the lipid production in oleaginous yeasts such as strain improvement through genetic engineering, optimization of the culture conditions (temperature, $\mathrm{pH}$, agitation rate), and cultivation in a modified bioreactor. Some of the cost-effective strategies is of specific nutritional supplementation in the cultivating medium like the addition of sodium lignosulfonate $(0.2 \% \mathrm{w} / \mathrm{v})$ for growing R. toruloides, significantly increased the lipid content by $44.9 \%$ [21]. Altering the nutritional composition of the cultivating medium also controls the FAME composition. Recently an oleaginous yeast Rhodosporidium toruloides DSM 4444 was grown in presence of high amount of $\mathrm{NaCl}(6 \% ; \mathrm{w} / \mathrm{v})$ without pre-sterilization of the cultivation medium that further reduce the overall production cost. Moreover, $\mathrm{NaCl}(4.0 \% \mathrm{w} / \mathrm{v})$ supplementation causes boosted lipid accumulation $(71.3 \% \mathrm{w} / \mathrm{w})$ in $R$. toruloides [22]. The addition of various natural compounds such as essential oils, cyclopropane fatty acids, anthocyanins and organic acids in the cultivating medium also lead to tailor-made lipids production [17,23]. Some of these compounds are responsible for altering the fatty acid profile by modifying the activity of some elongases and desaturases of oleaginous yeast [15,23-25], while in another report the lipid accumulation of $R$. toruloides improved without affecting its fatty acid compositions when supplemented with some anionic surfactants [21].

Earlier reports indicate that the limitation of certain essential elements (nitrogen, phosphorus, zinc, Fe or $\mathrm{Mg}$ ) with excess carbon source in the provided culture medium also promoted lipid synthesis in oleaginous microorganisms [9]. Nitrogen limitation is an extensively studied phenomenon to stimulate the lipid accumulation in oleaginous microorganisms. Researcher have reported that under high $\mathrm{C} / \mathrm{N}$ molar ratio of 22.3 (in nitrogen limitation) oleaginous yeast accumulates high lipid content of $63.3 \%$ [26]. The lipid accumulation is a molecular process that differs in oleaginous and non-oleaginous yeasts. Lipid accumulation in oleaginous yeast started with the metabolization of sugar into pyruvate via glycolysis and pentose phosphate pathway [10]. Pyruvate is then transported into mitochondria and form acetyl co-A which further get metabolized by tricarboxylic acid cycle (TCC). The most imperative enzyme of TCC is isocitrate dehydrogenase (IDH) that totally depends on the concentration of AMP. In N limitation conditions, AMP is deaminated to IMP and inhibits the function of IDH. Isocitrate accumulates and equilibrates with citrate that goes in the cytoplasm via citrate/malate translocase. Citrate is further degraded by ATP-citrate lyase (ACL) into acetyl Co-A and oxaloacetate [7]. Oxaloacetate goes back in mitochondria and ACC to form malonyl Co- A with the use of acetyl Co-A as a substrate that finally forms triacylglycerols [27]. Non-oleaginous yeasts under the same growth conditions do not accumulate lipid because of 3-4 times lower intramitochondrial citrate levels than oleaginous yeast and rates of citrate efflux in the presence of L-malate are approximately 2.5times greater in oleaginous than in non-oleaginous yeasts [28]. Phosphorus is also an essential element for the growth of yeasts to maintain various metabolic activities such as synthesis of DNA and phospholipids. It was earlier reported that when Arabidopsis thaliana was grown under phosphate limited condition, the synthesis of phospholipids decreased while TAG content increased dramatically [29] while in photosynthetic bacteria, Rhodobacter sphaeroides, phosphate limitation causes the change of membrane phospholipids into non-phosphorus betaine lipids [30]. However, detail pathway of $P$ limitation in oleaginous yeast is still not known till date. To see the effect of phosphorus limitation on the growth and lipid accumulation, Wu et al. performed an experiment on oleaginous yeast strain Rhodosporidium toruloides Y4 that showed $62.2 \%$ of lipid content accumulation under high C/P molar ratio of 9552 along with low $\mathrm{C} / \mathrm{N}$ molar ratio of 6 [26]. The $p$-limitation strategy seems to be very useful for microorganisms where the feedstocks are full of nitrogen sources. Although the effect of $\mathrm{N}$ and $\mathrm{P}$ starvation alone in the medium has been studied in much detail by several authors, little is known about the effect of both $\mathrm{N}$ and $\mathrm{P}$ deficiency together and therefore its role in lipid metabolism of $R$. kratochvilovae has been deciphered in this study. The lipid content of synchronized $\mathrm{N}$ and $\mathrm{P}$ limitation was $(60.34 \pm 0.69 \%, \mathrm{w} / \mathrm{w})$ higher than $\mathrm{N}$ and $\mathrm{P}$ limitation alone. A significant question addressed in this study was the morphological variations in the structure of yeast lipid droplets (LDs) in response to changes in culture conditions, especially to the cultivation of cells in double limitation of nutrients ( $\mathrm{N}$ and $\mathrm{P}$ ). LDs of various sizes have been observed in different conditions ( $\mathrm{N}$ and $\mathrm{P}$ limitations). During the last decade, the research on lipid droplets increases tremendously due to their role as lipid buffer, oil storage and their involvement in human diseases. However, we are only at the beginning to understand metabolic functions which are attributed to this compartment. This study extends our recent knowledge about the molecular mechanism of changes in structure and size of lipid droplets based on the medium or nutritional requirement of the cell. The maximum lipid content $(60.34 \pm 0.69 \%, w / w)$ was observed in the condition where the both essentials nutrients ( $\mathrm{N}$ and $\mathrm{P}$ ) were in limited condition, further the mechanism of lipid accumulation in P-limited condition has been deciphered by TLC densitometer that showed the decrease in phospholipids content. Biodiesel obtained after down streaming processing were rich in monounsaturated fatty acids (MUFA) and low in polyunsaturated fatty acids (PUFA) which provide greater performance at low temperature (cold flow plugging properties) and high oxidative stability. Moreover, our new strategy can be utilized for biodiesel production from low $\mathrm{N}$ and $\mathrm{P}$ containing feedstocks in their natural environmental condition like Cassia fistula $\mathrm{L}$. fruit pulp containing $0.329 \mathrm{~g} / \mathrm{l}$ $\mathrm{N}$, and $0.0078 \pm 0.43 \mathrm{~g} / \mathrm{l}$ phosphorus [31], pulp and paper industry effluent containing $0.187 \pm 29 \mathrm{~g} / \mathrm{l} \mathrm{N}$ and $0.05 \mathrm{~g} / \mathrm{l} \mathrm{P}$ [32], Jerusalem 
artichoke containing low amount of total N, $0.53 \pm 0.01 \mathrm{~g} / 100 \mathrm{~g}$ of wet weight [33], corn stalk hydrolysates containing $0.23 \mathrm{~g} / \mathrm{L}$ total nitrogen [34] etc.

\section{Materials and methods}

\subsection{Microorganism and cultivating condition}

Earlier isolated red oleaginous yeast $R$. kratochvilovae HIMPA1 (Gene Bank Acc. No. KF772881) was used in this study to explore the effect of dual nutrient limitation of $\mathrm{N}$ and $\mathrm{P}$ on the growth and lipid accumulation [35]. The culture was maintained on YPD agar (2\%) plates and subculture once in a month. For the seed culture, yeast was grown in $50 \mathrm{ml} \mathrm{YEPD} \mathrm{broth} \mathrm{at} 30^{\circ} \mathrm{C}$ for $48 \mathrm{~h}$ and the cells were harvested followed by the washing with sterilized distilled water to remove the media components. The cells were suspended in $0.9 \%$ sterilized saline to attain cell density of $6.5-7.8 \times 10^{8}$ cells $/ \mathrm{ml}$.

\subsection{Preparation of nutrients limited media for lipid production}

The glucose synthetic media (GSM) used in this experiment as control contains (g/l): Glucose, 70; Salt solution: $\mathrm{KH}_{2} \mathrm{PO}_{4}, 1 ; \mathrm{MgSO}_{4}$, 0.5; $\left(\mathrm{NH}_{4}\right)_{2} \mathrm{SO}_{4}, 5.0 ; \mathrm{CaCl}_{2}, 0.1$; Trace elements $(\mathrm{mg} / \mathrm{l})$ : boric acid, $0.5, \mathrm{CuSO}_{4}, 0.04, \mathrm{KI}, 0.1 ; \mathrm{FeCl}_{3}, 0.2 ; \mathrm{MnSO}_{4}, 0.4 ; \mathrm{NaMO}_{3}, 0.2 ; \mathrm{ZnSO}_{4}$, 0.4 ; Vitamin solution $(\mathrm{mg} / \mathrm{l})$ : D-Biotin, 0.002 ; calcium pantothenate, 0.4; folic acid 0.002; inositol 0.20; niacin, 0.4; PABA, 0.2; pyridoxine $\mathrm{HCl} 0.4$; riboflavin 0.2 ; thiamine, 0.4 . For the optimization of nitrogen and phosphorus content in the glucose synthetic medium, spot test analysis was conducted using various agar plates containing different concentration of nitrogen sources such as Urea, $\mathrm{NH}_{4} \mathrm{Cl}, \mathrm{NH}_{4} \mathrm{NO}_{3},\left(\mathrm{NH}_{4}\right)_{2} \mathrm{SO}_{4}(1,5,10$ and $50 \mathrm{~g} / \mathrm{l})$ and phosphorus sources such as $\mathrm{KH}_{2} \mathrm{PO}_{4}, \mathrm{NaH}_{2} \mathrm{PO}_{4}, \mathrm{~K}_{2} \mathrm{HPO}_{4}, \mathrm{Na}_{2} \mathrm{HPO}_{4}$ (1, 5 and $10 \mathrm{~g} /$ 1). All of these plates were supplemented with complete supplement mixture (CSM; $1.7 \mathrm{~g} / \mathrm{l})$ and YNB $(0.79 \mathrm{~g} / \mathrm{l})$. The next day we made a serial dilution of fresh yeast cells in order to reach, $1 \times 10^{-5}$, $1 \times 10^{-4,} 1 \times 10^{-3}, 1 \times 10^{-2}, 1 \times 10^{-1}$ cell $/ \mathrm{ml}$ with Bürker chamber. From each one of these dilutions of the yeast cell, we spotted $10 \mu \mathrm{l}$ drops on plates containing the different growth media with different carbon, nitrogen, and phosphate sources at the indicated concentration. We serially plated $1 \times 10^{-5}, 1 \times 10^{-4}, 1 \times 10^{-3}$, $1 \times 10^{-2}, 1 \times 10^{-1}$ cells per spot. To study the effects of nitrogen and phosphorus under limiting condition on the growth and lipid synthesis in cellular compartment of $R$. kratochvilovae HIMPA1, $\left(\mathrm{NH}_{4}\right)_{2} \mathrm{SO}_{4}$ (showing best growth) concentrations were reduced from $5.0 \mathrm{~g} / \mathrm{l}$ to $0.1 \mathrm{~g} / \mathrm{l}$ and $\mathrm{KH}_{2} \mathrm{PO}_{4}$ from $1 \mathrm{~g} / \mathrm{l}$ to $0.05 \mathrm{~g} / \mathrm{l}$, respectively in distinct experiments. To investigate the combined effect of both nutrients limitation, the nitrogen and phosphorus concentration were $0.1 \mathrm{~g} / \mathrm{l}$ and $0.05 \mathrm{~g} / \mathrm{l}$, respectively. Batch cultivations were performed in $500 \mathrm{ml}$ Erlenmeyer flasks at $30{ }^{\circ} \mathrm{C}$ for $240 \mathrm{~h}$ with $180 \mathrm{rpm}$. The glucose content and amount of nitrogen and phosphorus in the medium of batch cultivation experiments were estimated by using the protocol of Patel et al. [35].

\subsection{Estimation of cell dry weight and lipid content}

In order to estimate the cell dry weight, $50 \mathrm{ml}$ culture was harvested by centrifugation and the obtained pellets were kept on preweighed filter paper. The filter paper along with biomass was oven dried overnight at $60{ }^{\circ} \mathrm{C}$ and weighed using an analytical balance. The cell dry weight of $R$. kratochvilovae HIMPA1 was expressed $\mathrm{g} / \mathrm{l}$. For the lipid content $(\%, \mathrm{w} / \mathrm{w})$, the harvested cells were used for lipid extraction by the protocol described earlier in Patel et al., 2014 [35]. Lipid yield (g/l) was determined by gravimetric analysis of extracted lipids from the cellular biomass while lipid content was calculated by the following equation-
Lipid content $(\%, w / w)=\frac{\operatorname{Lipid} \text { yield }(\mathrm{g} / \mathrm{l})}{\text { Cell dry weight }(\mathrm{g} / \mathrm{l})} \times 100$

\subsection{Analysis of morphological variation and TAG accumulation in R. kratochvilovae HIMPA1}

The morphological variation during various nutrient limitations and TAG accumulation in the form of LDs in cellular compartments of $R$. kratochvilovae HIMPA1 were observed by live fluorescence microscopy protocol described in Patel et al. [35]. In brief, $1 \mathrm{ml}$ of cell culture was harvested by centrifugation at $5000 \mathrm{rpm}$ for $5 \mathrm{~min}$ and washed with saline water three times to remove media com-

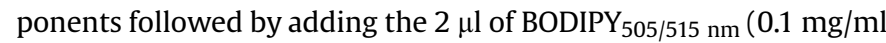
DMSO) and incubated for $5 \mathrm{~min}$ at room temperature. The fluorescence microscopy was carried out using a digital inverted fluorescence microscope (EVOS- FL, AMG, USA) equipped with EVOS light cube GFP. The morphological variations and lipid droplets accumulation were examined by Image 1.48 a software with the help of collected images having statistically significant data.

\subsection{Lipid composition analysis by thin layer chromatography (TLC)}

Compositional analysis of the extracted lipids were carried out by TLC using 0.25-mm-thick silica gel G-60 F254 plates (Merck, India) and chromatograms were developed by double development method of TLC [36]. The plate was initially developed to $2.5 \mathrm{~cm}$ from the origin with hexane: tert-butyl methyl ether: acetic acid (50:50:0.5, v/v/v), and after air dried, redeveloped to $8 \mathrm{~cm}$ from the origin with hexane: tert-butyl methyl ether: acetic acid (97:3:0.5, v/ $\mathrm{v} / \mathrm{v}$ ) as a developing agent. The samples were visualized by spraying sulphuric acid $50 \%(\mathrm{w} / \mathrm{w})$ and then heating at $135^{\circ} \mathrm{C}$. After staining, the plate was scanned with Canon Scanner at a fix resolution of 300 dpi and obtained image was processed with Image J 4.18a software for measurement of optical density in the areas of different spots.

\subsection{FAME analysis by TLC}

Extracted lipids were converted into fatty acid methyl esters (FAME) with transesterification reaction by using the protocol of Patel et al. [35]. Transesterified samples were loaded on the Silicagel TLC-plate (Silica gel $60 \mathrm{~F}_{254}$, Merck, Germany) [37]. The standards for triacylglycerol (Triolein) and FAME (Palmitic acid methyl esters) were spotted in lane 1 . The development was carried out in TLC chamber with $15 \%$ ethyl acetate in hexane as solvent. After drying, the plates were further developed in water for homogeneous saturation. The plate was immersed in $100 \mathrm{ml}$ of $1 \%$ solution of $\mathrm{KMnO}_{4}$ in $4 \% \mathrm{NaOH}$ for $20 \mathrm{~s}$ followed by washing with water for 3-4 times. After staining, the plate was scanned with Canon Scanner at a fix resolution of $300 \mathrm{dpi}$ and obtained image is processed with Image J 4.18a software for measurement of optical density in the areas of different spots.

\subsection{Determination of fatty acid methyl ester composition by GC-MS analysis and biodiesel properties}

FAME samples were analyzed by GC-MS (Agilent, Santa Clara, CA, USA) equipped with the capillary column (DB- 5MS; dimensions $30 \mathrm{~m} \times 0.25 \mathrm{~mm}$ ID and $0.25 \mu \mathrm{m}$ film thicknesses). The column was initially set for $1.5 \mathrm{~min}$ at $50^{\circ} \mathrm{C}$ and the temperature was increased to $180^{\circ} \mathrm{C}$ for $1 \mathrm{~min}$ with the rate of $25^{\circ} \mathrm{C} / \mathrm{min}$. It was further increased to $280{ }^{\circ} \mathrm{C}$ for $1 \mathrm{~min}$ with the rate of $10{ }^{\circ} \mathrm{C} / \mathrm{min}$. Finally, the temperature was ramped to $250{ }^{\circ} \mathrm{C}$ for $3 \mathrm{~min}$ with the 
rate of $15^{\circ} \mathrm{C} / \mathrm{min}$. The sample $(1 \mu \mathrm{l})$ was injected in splitless mode at $250^{\circ} \mathrm{C}$. All the samples were analyzed with the help of electron ionization $(70 \mathrm{eV})$ in scan mode $(50-600 \mathrm{~m} / \mathrm{z})$. Library search report and retention time were used to identify FAME presence in TAG-derived from nutrient stressed Rhodosporidium kratochvilovae HIMPA1. The empirical formulas were derived for estimation of biodiesel properties such as SV (saponification value; mg $\mathrm{KOH}$ ), IV (iodine value; $\mathrm{gI}_{2} / 100 \mathrm{~g}$ ), $\mathrm{CN}$ (cetane number), DU (degree of unsaturation; \% wt), (LCSF long chain saturation factor; \% wt), CFPP (cold filter plugging point; ${ }^{\circ} \mathrm{C}$ ), $\mathrm{HHV}$ (high heating value; $\mathrm{MJ} \mathrm{Kg}^{-1}$ ), $\mathrm{KV}$ (kinematic viscosity, $v_{\mathrm{i}} ; 40^{\circ} \mathrm{C}$ in $\left.\mathrm{mm}^{2} \mathrm{~s}^{-1}\right)$, density $\left(\rho ; 20^{\circ} \mathrm{C}\right.$ in $\mathrm{g}$ $\mathrm{cm}^{-3}$ ) and OS (oxidative stability; h) [38-41].

$$
\begin{aligned}
& \mathrm{SV}=\sum 560(\% \mathrm{FC}) / \mathrm{M} \\
& \mathrm{IV}=\sum 254 \mathrm{DB} \times \% \mathrm{FC} / \mathrm{M} \\
& \mathrm{CN}=46.3+5458 / \mathrm{SV}-(0.255 \times \mathrm{IV}) \\
& \mathrm{DU}(\%)=\mathrm{MUFA}+(2 \times \mathrm{PUFA}) \\
& \mathrm{LCSF}=(0.1 \times \mathrm{C} 16)+(0.5 \times \mathrm{C} 18) \\
& \mathrm{CFPP}=(3.417 \times \mathrm{LCSF})-16.477 \\
& \mathrm{HHV}=49.43-0.041(\mathrm{SV})-0.015(\mathrm{IV}) \\
& \ln (\mathrm{KV})=-12.503+2.496 \times \ln \left(\sum \mathrm{M}\right)-0.178 \times \sum \mathrm{DB} \\
& \text { Density }=0.8463+4.9 / \sum \mathrm{M}+0.0118 \times \sum \mathrm{DB} \\
& \text { OS }=117.9295 /(\mathrm{wt} \% \mathrm{C} 18: 2+\mathrm{wt} \% \mathrm{C} 18: 3)+2.5905
\end{aligned}
$$

where $\mathrm{M}=$ molecular mass of each fatty acid component, $\mathrm{DB}=$ number of double bonds, $\mathrm{FC}=\%$ of each fatty acid component, MUFA = weight $\%$ of monounsaturated fatty acids, PUFA = weight $\%$ of poly unsaturated fatty acid.

\subsection{Experimental determination of SV and IV}

The saponification value (SV) of the oleaginous yeast oil was determined by AOCS method [42]. In brief, $1 \mathrm{~g}$ yeast oil sample was mixed in $12.5 \mathrm{ml}$ of $0.5 \mathrm{~N}$ ethanolic potassium hydroxide. The oil droplets were dissolved in the ethanolic $\mathrm{KOH}$ after refluxing of mixture for $20 \mathrm{~min}$. The mixture was cooled at room temperature $\left(25{ }^{\circ} \mathrm{C}\right)$ followed by addition of Phenolphthalein indicator. The obtained solution was titrated with $0.5 \mathrm{~N} \mathrm{HCl}$ until the pink color disappears. A blank titration was also carried out in the same manner except that no oil was added. It was calculated using the formula:

$$
S V=\frac{56.1(c-t) \times N}{W}
$$

where, $\mathrm{c}=$ Volume $(\mathrm{ml})$ of $0.5 \mathrm{~mol} / \mathrm{l} \mathrm{HCl}$ consumed in the blank test, $\mathrm{t}=$ Volume $(\mathrm{ml})$ of $0.5 \mathrm{~mol} / 1 \mathrm{HCl}$ consumed in the test, $\mathrm{N}=$ Normality of $\mathrm{HCl}, \mathrm{W}=$ Weight of oil sample.

The Iodine Value (IV) of the oleaginous yeast oil was determined by AOCS method [42]. $0.1 \mathrm{~g}$ oil sample was mixed with $20 \mathrm{ml}$ carbon tetrachloride in a conical flask and sealed with stopper. The mixture was subjected to sonication in a sonicator bath followed by addition of $25 \mathrm{ml}$ Hanus solution. After vortexing, the mixture was kept in dark at $20{ }^{\circ} \mathrm{C}$ for $30 \mathrm{~min} .15 \%$ potassium iodide $(10 \mathrm{ml})$ and $100 \mathrm{ml}$ water were added into mixture, sealed and vortex for $30 \mathrm{~s}$. The mixture was titrated with $0.1 \mathrm{~mol} / 1$ sodium thiosulfate to obtain iodine value. Similarly, blank test was performed to obtain blank level.

$I V=\frac{127(c-t) \times N}{10 W}$

where; $\mathrm{c}=$ Volume $(\mathrm{ml})$ of $0.1 \mathrm{~mol} / 1$ sodium thiosulfate consumed in the blank test, $\mathrm{t}=$ Volume $(\mathrm{ml})$ of $0.5 \mathrm{~mol} / \mathrm{l}$ sodium thiosulfate consumed in the test, $\mathrm{N}=$ Normality of sodium thiosulfate, $\mathrm{W}=$ Weight of sample.

\subsection{Statistical analysis}

The data values are means \pm standard deviation of three independent recorded values. One-way analysis of variance (ANOVA) using Microsoft Office Excel 2013 (Microsoft, USA) with $\mathrm{p}<0.05$ was used for data acceptance.

\section{Results and discussion}

\subsection{Effect of synchronized nutritional stress conditions on the growth and lipid accumulation of Rhodosporidium kratochvilovae HIMPA1}

Lipid accumulation in the cellular compartment of oleaginous microorganisms is totally dependent on the metabolic accessibility of provided nutrients. Oleaginous yeasts showed enhanced lipid accumulation while grown in a condition of nutrient limitation with excess of carbon sources [43]. It has been previously reported that medium components such as carbon, nitrogen, phosphorus, sulfur and their ratios $(\mathrm{C} / \mathrm{N}, \mathrm{C} / \mathrm{P}, \mathrm{C} / \mathrm{S})$ revealed significant influence on the growth and lipid accumulation of oleaginous yeasts $[26,43,44]$. The synthetic medium used in this study for the cultivation of Rhodosporidium kratochvilovae HIMPA1 was also optimized for maximum biomass production using various nitrogen (Urea, $\left.\mathrm{NH}_{4} \mathrm{Cl},\left(\mathrm{NH}_{4}\right)_{2} \mathrm{SO}_{4}, \mathrm{NH}_{4} \mathrm{NO}_{3}\right)$ and phosphorous $\left(\mathrm{KH}_{2} \mathrm{PO}_{4}\right.$, $\mathrm{NaH}_{2} \mathrm{PO}_{4}, \mathrm{~K}_{2} \mathrm{HPO}_{4}, \mathrm{Na}_{2} \mathrm{HPO}_{4}$ ) sources by implying spot test method (Supplementary data Fig. 1). It was observed that among the different sources tested, the growth on $\left(\mathrm{NH}_{4}\right)_{2} \mathrm{SO}_{4}$ at $5 \mathrm{~g} / \mathrm{l}$ for nitrogen (Supplementary data Fig. 1 ) and $\mathrm{KH}_{2} \mathrm{PO}_{4}$ at $1 \mathrm{~g} / \mathrm{l}$ for P were optimum for maximum biomass formation under normal conditions in glucose synthetic medium (GSM). The present study deals with the effect of nutrients (nitrogen and phosphorus) limitation alone and in synchronized manner on the growth and lipid accumulation of oleaginous yeast $R$. kratochvilovae HIMPA1 and compared with the conditions of optimized nutrients in GSM used as control (Table 1). The other Rhodosporidium species grown on different carbon sources are also compared for their cell dry weight $(\mathrm{g} / \mathrm{l})$, total lipid yield $(\mathrm{g} / \mathrm{l})$ and lipid content $(\% \mathrm{w} / \mathrm{w})$ (Table 2$)$. The batch cultivation experiments for cell dry weight, total lipid yield, lipid content, residual glucose, nitrogen and phosphorus under nutritional stress conditions in $R$. kratochvilovae HIMPA1 is presented in Fig. 1. The carbon source for each batch experiments was glucose $(70 \mathrm{~g} / \mathrm{l}$ or $7 \%$; w/v). The cell dry weight was reported to decrease constantly with the depletion of nitrogen concentration in the medium from $5 \mathrm{~g} / 1$ to $0.1 \mathrm{~g} / \mathrm{l}$. The highest cell dry weight ( $13.26 \mathrm{~g} / \mathrm{l})$ obtained when cells were grown in $5 \mathrm{~g} / \mathrm{l}$ nitrogen while at $0.1 \mathrm{~g} / \mathrm{l} \mathrm{N}$ the cell dry weight was minimum $(9.23 \mathrm{~g} / \mathrm{l})$. $R$. kratochvilovae HIMPA1 cells showed reduced cellular metabolic activity (as measured by XTT assay) and number of cell divisions under nitrogen limited condition (data not shown). However, it was interesting to note that the cells exhibit lipid accumulation in the 


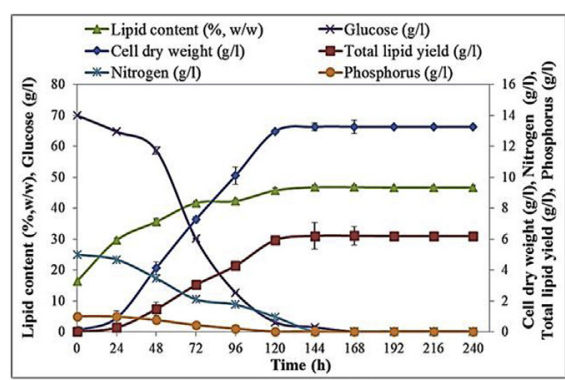

(A) N 5g/l and P 1g/l

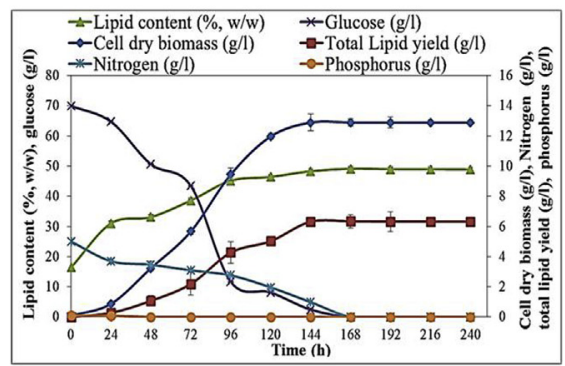

(D) $\mathrm{N} 5 \mathrm{~g} / \mathrm{l}$ and $\mathrm{P} 0.1 \mathrm{~g} / \mathrm{l}$

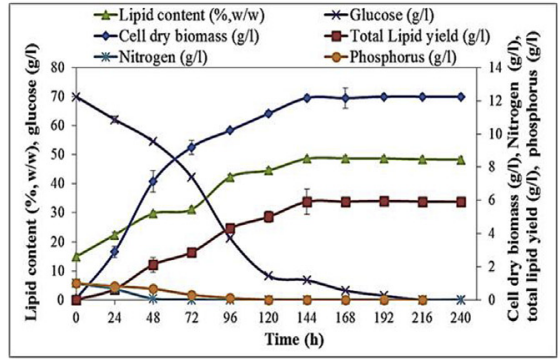

(B) N 1g/l and P1g/l

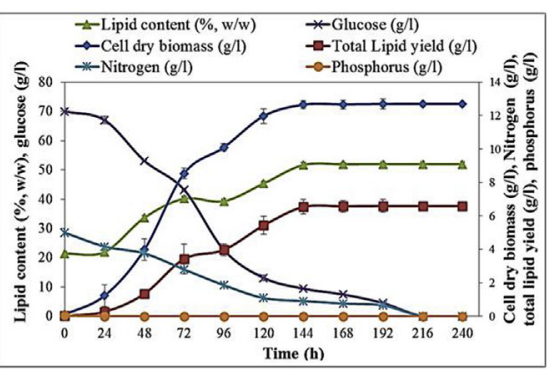

(E) N 5g/l and P 0.05g/l

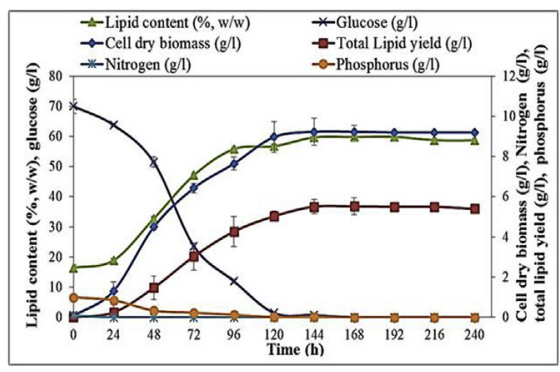

(C) N 0.1g/l and P 1g/l

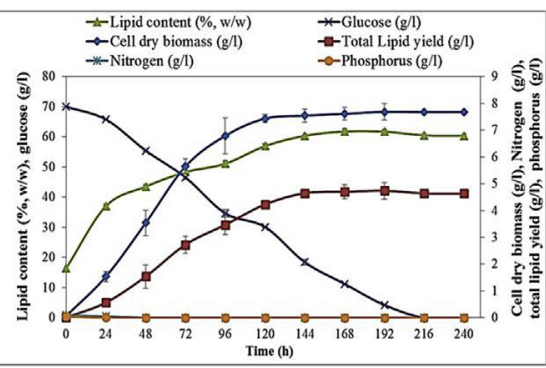

(F) $\mathrm{N} 0.1 \mathrm{~g} / \mathrm{l}$ and $P 0.05 \mathrm{~g} / \mathrm{l}$

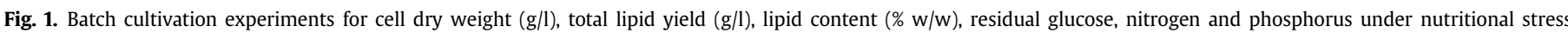
conditions in R. kratochvilovae HIMPA1.

Table 1

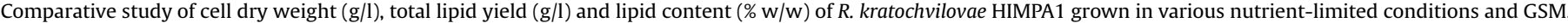

\begin{tabular}{|c|c|c|c|c|c|}
\hline $\begin{array}{l}\text { Cultivation medium } \\
\text { containing ( } \mathrm{N} \text { and } \mathrm{P})\end{array}$ & $\begin{array}{l}\text { Cell dry } \\
\text { weight }(\mathrm{g} / \mathrm{l})\end{array}$ & $\begin{array}{l}\text { Total lipid } \\
\text { yield }(\mathrm{g} / \mathrm{l})\end{array}$ & $\begin{array}{l}\text { Lipid content } \\
(\%, w / w)\end{array}$ & $\begin{array}{l}\text { Total cell dry } \\
\text { weight }(\mathrm{g} / \mathrm{g})^{\mathrm{a}}\end{array}$ & $\begin{array}{l}\text { Lipid yield } \\
(\mathrm{g} / \mathrm{g})^{\mathrm{b}}\end{array}$ \\
\hline $5 \mathrm{~g} / \mathrm{l} \mathrm{N} ; 1 \mathrm{~g} / \mathrm{l} \mathrm{P}$ (control) & $13.26 \pm 0.98$ & $6.2 \pm 0.58$ & $46.76 \pm 0.61$ & 0.189 & 0.088 \\
\hline $1 \mathrm{~g} / \mathrm{l} \mathrm{N} ; 1 \mathrm{~g} / \mathrm{l} \mathrm{P}$ & $12.17 \pm 034$ & $5.92 \pm 0.76$ & $48.64 \pm 0.45$ & 0.173 & 0.084 \\
\hline $0.1 \mathrm{~g} / \mathrm{l} \mathrm{N} ; 1 \mathrm{~g} / \mathrm{l} \mathrm{P}$ & $9.23 \pm 0.65$ & $5.51 \pm 0.32$ & $59.69 \pm 0.65$ & 0.131 & 0.078 \\
\hline $5 \mathrm{~g} / \mathrm{l} \mathrm{N} ; 0.1 \mathrm{~g} / \mathrm{l} \mathrm{P}$ & $12.89 \pm 0.37$ & $6.32 \pm 0.45$ & $48.33 \pm 0.53$ & 0.184 & 0.090 \\
\hline $5 \mathrm{~g} / \mathrm{l} \mathrm{N} ; 0.05 \mathrm{~g} / \mathrm{l} \mathrm{P}$ & $12.65 \pm 0.12$ & $6.54 \pm 0.87$ & $51.7 \pm 0.81$ & 0.180 & 0.093 \\
\hline $0.1 \mathrm{~g} / \mathrm{l} \mathrm{N} ; 0.05 \mathrm{~g} / \mathrm{l} \mathrm{P}$ & $7.54 \pm 0.65$ & $4.65 \pm 0.54$ & $60.34 \pm 0.69$ & 0.107 & 0.066 \\
\hline
\end{tabular}

a $\mathrm{g}$ of total cell dry biomass produced per $\mathrm{g}$ of substrate consumed.

b $\mathrm{g}$ of cellular lipids produced per $\mathrm{g}$ of substrate consumed.

Table 2

Rhodosporidium species grown on different carbon sources for lipid production.

\begin{tabular}{|c|c|c|c|c|c|c|}
\hline S. No. & Oleaginous Yeasts & Medium/mode of cultivation & $\begin{array}{l}\text { Dry cell } \\
\text { weight }(g / 1)\end{array}$ & $\begin{array}{l}\text { Total lipid } \\
\text { yield }(\mathrm{g} / \mathrm{l})\end{array}$ & $\begin{array}{l}\text { Lipid content } \\
(\%, w / w)\end{array}$ & References \\
\hline 1 & Rhodosporidium toruloides 21167 & Cassava starch/2-1 co-culture bioreactor & 20.1 & 13.04 & 64.9 & [69] \\
\hline 2 & Rhodosporidium toruloides 2F5 & Inulin & 15.82 & 9.83 & 62.14 & {$[70]$} \\
\hline 3 & Rhodosporidium fluviale DMKU-RK253 & $\begin{array}{l}\text { Crude glycerol-YM (yeast extract- malt extract) } \\
\text { medium } / 5 \mathrm{~L} \text { jar fermenter }\end{array}$ & 14.09 & 8.99 & 63.8 & [71] \\
\hline 4 & Rhodosporidium toruloides AS 2.1389 & $\begin{array}{l}\text { Acetic acid/carbon-to-nitrogen ratio }(\mathrm{C} / \mathrm{N}) \text { of } 200 \\
\text { in a batch culture }\end{array}$ & 4.35 & 2.1 & 48.2 & [72] \\
\hline 5 & Rhodosporidium diobovatum (08-225) & pinewood pyrolytic sugars $100 \%$ & 17.53 & 4.08 & 23.27 & [73] \\
\hline 6 & Rhodosporidium fluviale DMKU-SP314 & glucose and xylose & 14.3 & 7.9 & 55.24 & [74] \\
\hline 7 & Rhodosporidium toruloides DEBB 5533 & $\begin{array}{l}\text { Sugarcane juice/batch cultivation (1000 L } \\
\text { working volume }\end{array}$ & 24.5 & 10.1 & 41.22 & [18] \\
\hline 8 & Rhodosporidium toruloides ATCC 10788 & Crude glycerol media. & 21.16 & 11.27 & 53.28 & [75] \\
\hline 9 & R. kratochvilovae HIMPA1 & Aqueous extract of Cassia fistula L. (CAE) fruit pulp & 8.9 & 4.86 & 53.18 & [31] \\
\hline 10 & R. kratochvilovae HIMPA1 & Pulp and paper industry effluent & 13.87 & 8.56 & 61.71 & [32] \\
\hline 11 & R. kratochvilovae HIMPA1 & GSM containing $5 \mathrm{~g} / \mathrm{l} \mathrm{N} ; 1 \mathrm{~g} / \mathrm{l} \mathrm{P}$ (control) & 13.26 & 6.2 & 46.76 & This study \\
\hline 12 & R. kratochvilovae HIMPA1 & GSM containing $0.1 \mathrm{~g} / \mathrm{l} \mathrm{N} ; 1 \mathrm{~g} / \mathrm{l} \mathrm{P}$ & 9.23 & 5.51 & 59.69 & This study \\
\hline 13 & R. kratochvilovae HIMPA1 & GSM containing $5 \mathrm{~g} / \mathrm{l} \mathrm{N} ; 0.05 \mathrm{~g} / \mathrm{l} \mathrm{P}$ & 12.65 & 6.54 & 51.7 & This study \\
\hline 14 & R. kratochvilovae HIMPA1 & GSM containing $0.1 \mathrm{~g} / 1 \mathrm{~N}+0.05 \mathrm{~g} / \mathrm{l} \mathrm{P}$ & 7.54 & 4.65 & 60.34 & This study \\
\hline
\end{tabular}

opposite manner regardless of their growth. The highest lipid content $(59.69 \%)$ was observed with the nitrogen $(0.1 \mathrm{~g} / \mathrm{l})$ limited condition. The TLC chromatogram of extracted lipids from oleaginous yeast grown under various nutrient stress conditions is presented in Fig. 2A. Quantitative measurement of optical density in the areas of different spots is presented in Fig. 2B. The amount of TAG, FFA, St, PE and PC $(\%, w / w)$ in obtained total lipid $(\mathrm{g} / \mathrm{l})$ were calculated according to their corresponding area represented in 


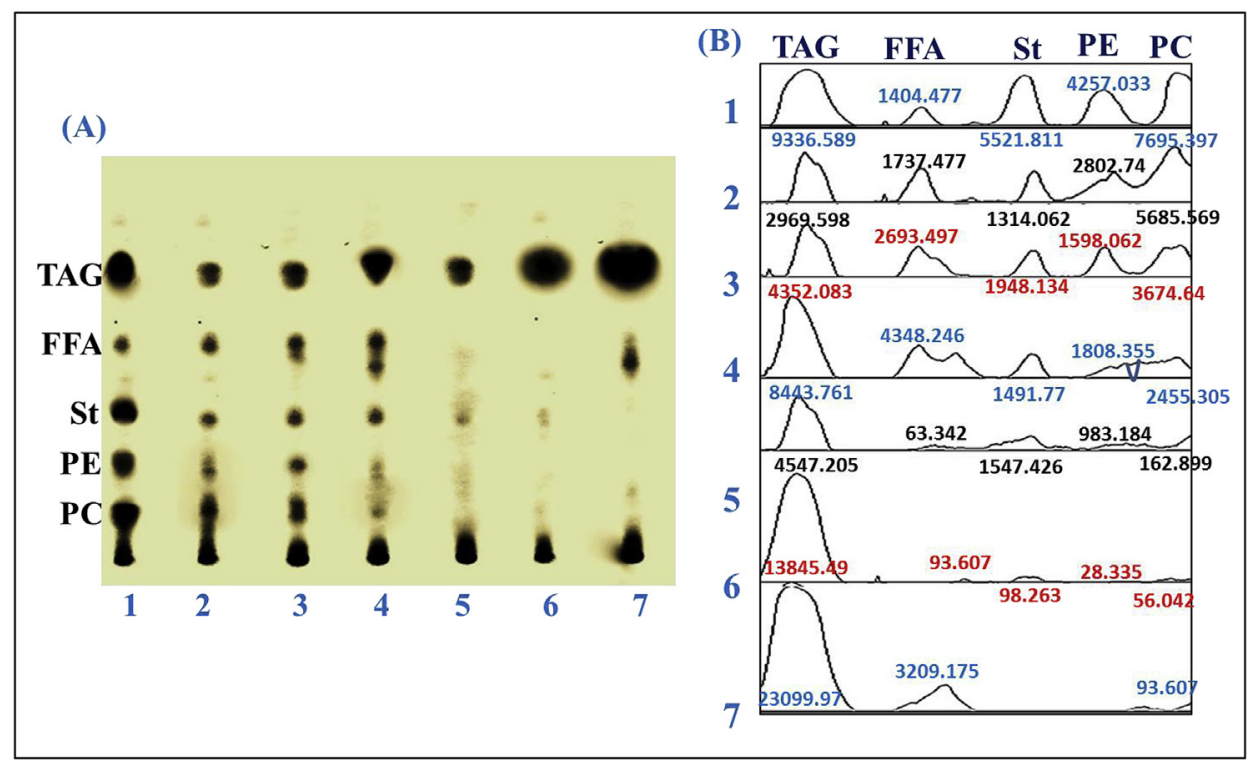

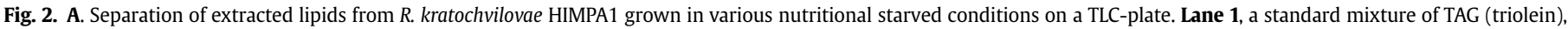

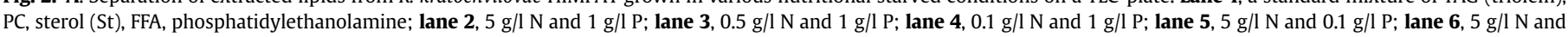

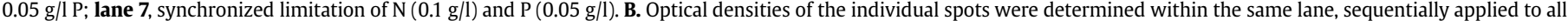
lanes. Areas of the spots plotted as the functions of the corresponding masses.

Fig. 2B (Table 3). The data of lane 3 and 4 depict increased TAG content in LDs (31.77\% and 64.83\%) in N-limited condition $(1 \mathrm{~g} / \mathrm{l}$ and $0.1 \mathrm{~g} / \mathrm{l}$ ) respectively as compared to normal (without limitation, lane 2) while the scanty amount of FFA, PE and PC were present. These results validate the enhanced TAG accumulation in N-limited condition. Similar results was shown by Li et al. where $R$. toruloides Y4 accumulated more than $70 \%$ lipid content of their dry biomass in $\mathrm{N}$-limited medium ( $\mathrm{C} / \mathrm{N}$ molar ratios higher than 570$)$ however, in the lower $\mathrm{C} / \mathrm{N}$ molar ratios $(<100)$, lipid contents were decreased to $20 \%$ [45]. Mortierella isabellina, an oleaginous fungus observed to accumulate more than 50\% lipid content under the high (150-300) $\mathrm{C} / \mathrm{N}$ molar ratios [46]. Hassan et al. showed that oleaginous yeast Cryptococcus curvatus accumulate more lipid content with stearic acid (14\%) under the $\mathrm{N}$-limited condition, whereas, it was boosted by the combined effect of Fe and N-limited condition (19\%) [47]. Brauer et al. described the $\mathrm{N}$ regulation in yeast cells where the cells had reduced ribosomal synthesis and translation, that results in slow growth and enlargement of the G1 phase of the cell cycle under N-limited conditions [48]. Non-oleaginous yeast such as Saccharomyces cerevisiae and food yeast (Candida ultilis) cannot accumulate lipid content more than $10 \%$ of their total biomass [49], but when they grow in nitrogen-limited medium with excess carbon source the amount of mannans and glucans contents increases. However, in the case of oleaginous yeast, the excess carbon source get converted into lipid droplets in cellular compartment [28]. When nitrogen exhausts from the culture medium, Adenosine monophosphate deaminase gets activated and catalyzes the reaction of AMP to Inosine 5'-monophosphate (IMP) and Ammonium [43]. The Adenosine monophosphate deaminase enzyme is present in oleaginous yeast but no such absolute dependency in nonoleaginous yeast occurs [10]. Isocitrate dehydrogenase (ICDH) is inactivated when the concentration of AMP decreases and Isocitrate does not metabolize via Tricarboxylic acid cycle [28]. Isocitrate equilibrates with Citrate in the mitochondria. In the cytosol of oleaginous organisms, ATP: citrate lyases (ACL) cleaved Citrate and it translocate from mitochondria to the cytosol via Malate/ Citrate translocase shuttle pathway. It has been reported that $\mathrm{ACL}$ is not present in non-oleaginous microorganisms [7] that have a major role in the synthesis of triacylglycerols (Fig. 3). Acetyl-CoA formed in this reaction is converted into malonyl-CoA by acetylCoA carboxylase enzyme. In the de-novo synthesis of lipids, both acetyl-CoA and malonyl-CoA added to form fatty acid chains between 14 and 16 carbons long. Phosphatidic acid (PA) is a key enzyme for TAG and phospholipid (PL) synthesis. PL is converted into cytidine diphosphate-diacylglycerol (CDP-DG) by ER-localized CDP-DG synthase Cds1p or by the mitochondrial CDP-DG synthase Tam41p where CTP act as a donor of CDP [27]. CDP-DG further converted into phosphatidylinositol (PI), phosphatidylserine (PS), phosphatidylethanolamine (PE), and phosphatidylcholine (PC) by different synthases such as phosphatidylinositol synthase Pis1p; and phosphatidylserine synthase Cho1p (Fig. 3). Kennedy pathway is also another route for PE and PC synthesis using exogenous

Table 3

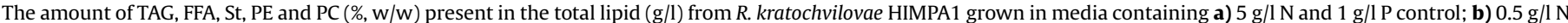
and $1 \mathrm{~g} / \mathrm{l} \mathrm{P}$; c) $0.1 \mathrm{~g} / \mathrm{l} \mathrm{N}$ and $1 \mathrm{~g} / \mathrm{l} \mathrm{P}$; d) $5 \mathrm{~g} / \mathrm{l} \mathrm{N}$ and $0.1 \mathrm{~g} / \mathrm{l} \mathrm{P}$; e) $5 \mathrm{~g} / \mathrm{l} \mathrm{N}$ and $0.05 \mathrm{~g} / \mathrm{l} \mathrm{P}$; f) synchronized limitation of $\mathrm{N}(0.1 \mathrm{~g} / \mathrm{l})$ and $\mathrm{P}(0.05 \mathrm{~g} / \mathrm{l})$.

\begin{tabular}{|c|c|c|c|c|c|c|c|}
\hline S. No. & Cultivation medium containing ( $\mathrm{N}$ and $\mathrm{P}$ ) & Total lipid yield (g/l) & TAG $(\% \mathrm{w} / \mathrm{w})$ & FFA $(\% \mathrm{w} / \mathrm{w})$ & St $(\% \mathrm{w} / \mathrm{w})$ & $\mathrm{PE}(\% \mathrm{w} / \mathrm{w})$ & $\mathrm{PC}(\% \mathrm{w} / \mathrm{w})$ \\
\hline $\mathrm{a}$ & $5 \mathrm{~g} / \mathrm{l} \mathrm{N} ; 1 \mathrm{~g} / \mathrm{l} \mathrm{P}$ (control) & $6.2 \pm 0.58$ & 20.46 & 11.97 & 9.06 & 19.32 & 39.19 \\
\hline b & $1 \mathrm{~g} / \mathrm{l} \mathrm{N} ; 1 \mathrm{~g} / \mathrm{l} \mathrm{P}$ & $5.92 \pm 0.76$ & 30.51 & 18.88 & 13.65 & 11.20 & 25.76 \\
\hline c & $0.1 \mathrm{~g} / \mathrm{l} \mathrm{N} ; 1 \mathrm{~g} / \mathrm{l} \mathrm{P}$ & $5.51 \pm 0.32$ & 45.53 & 23.45 & 8.03 & 9.76 & 13.23 \\
\hline d & $5 \mathrm{~g} / \mathrm{l} \mathrm{N} ; 0.1 \mathrm{~g} / \mathrm{l} \mathrm{P}$ & $6.32 \pm 0.45$ & 62.26 & 0.90 & 21.17 & 13.46 & 2.21 \\
\hline e & $5 \mathrm{~g} / \mathrm{l} \mathrm{N} ; 0.05 \mathrm{~g} / \mathrm{l} \mathrm{P}$ & $6.54 \pm 0.87$ & 98.05 & 0.68 & 0.69 & 0.19 & 0.39 \\
\hline $\mathrm{f}$ & $0.1 \mathrm{~g} / \mathrm{l} \mathrm{N} ; 0.05 \mathrm{~g} / \mathrm{l} \mathrm{P}$ & $4.65 \pm 0.54$ & 87.46 & 12.14 & nd & nd & 0.4 \\
\hline
\end{tabular}

nd; not detected. 


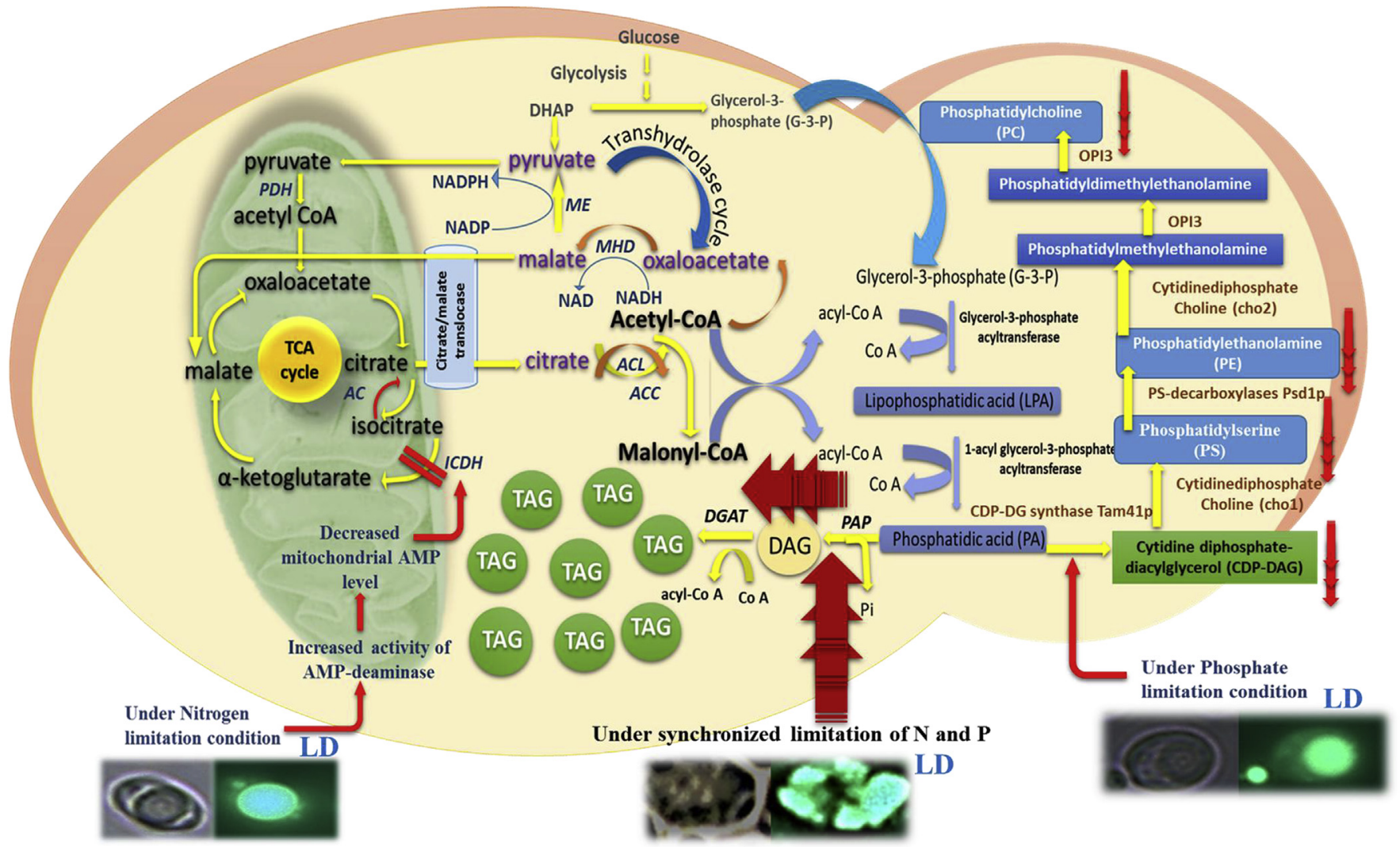

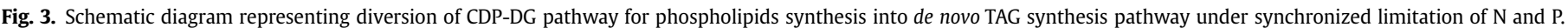

ethanolamine and choline synthesis [27].

The studies on the biosynthesis of intracellular carbohydrate and its relation to intracellular lipid synthesis in Cryptococcus curvatus NRRL Y-1511 have opened the fresh area of research for metabolites synthesis. This oleaginous yeast synthesized high quantities of intracellular carbohydrate (up to $68 \% \mathrm{w} / \mathrm{w}$ ) at the starting of fermentation process when grown in lactose or sucrose under nitrogen limiting condition while the amount was decreased to $20 \%, \mathrm{w} / \mathrm{w}$ at the end of the process. Complementary to the decline in carbohydrate level led to increase in lipid content under continuous intake of extracellular lactose. However, this situation was different in the presence of excess quantities of nitrogen in the medium higher quantities of intracellular carbohydrate was produced [50]. Boosted lipid accumulation is also reported in oleaginous yeast cells under $\mathrm{N}$-limited condition; however, it is difficult to attain high cell dry weight in such condition.

Another target for lipid accumulation in $R$. kratochvilovae HIMPA1 was phosphorus limitation in the medium that was effective irrespective of the presence of high amount of nitrogen in the medium. For the growth and lipid accumulation in oleaginous yeast cells, not only nitrogen but also phosphorus is an important factor that is assimilated for phospholipids, nucleic acid, and coenzymes formation in yeast cells. Additionally, phosphorus has the main role in the generation of metabolic energy in the form of ATP and NADP [51]. Batch cultivation experiments for phosphoruslimited conditions ( 0.1 and $0.005 \mathrm{~g} / \mathrm{l}$ ) without altering the concentration of nitrogen $(5 \mathrm{~g} / \mathrm{l})$ is represented in Fig. 1. The cell dry weight of $R$. kratochvilovae HIMPA1 was reported to be almost constant $(6.32 \pm 0.45 \mathrm{~g} / \mathrm{l}$ and $6.54 \pm 0.87 \mathrm{~g} / \mathrm{l})$ for both phosphorus starved conditions ( 0.1 and $0.05 \mathrm{~g} / \mathrm{l}$ ). Whereas $R$. kratochvilovae HIMPA1 was grown in the medium containing $0.1 \mathrm{~g} / \mathrm{l} \mathrm{P}$, the cell dry weight, and lipid yield were $12.89 \mathrm{~g} / \mathrm{l}$ and $6.32 \mathrm{~g} / \mathrm{l}$ respectively while at $0.05 \mathrm{~g} / \mathrm{l} \mathrm{P}$, the cell dry weight was $12.65 \mathrm{~g} / \mathrm{l}$ along with $6.54 \mathrm{~g} / 1$ lipid yield. Moreover, the lipid content has increased from $48.33 \%$ to $51.7 \%$ with the decreasing amount of P (Table 1 ). The results obtained from TLC of extracted lipids in lane 5 and lane 6 specifically showed $34.70 \%$ and $78.55 \%$ increased TAG contents of LDs in phosphorus starved conditions $(0.1$ and $0.05 \mathrm{~g} / \mathrm{l})$ than the normal condition (lane 2 ) while the content of FFA, PE (35.47\%) and PC (56.81\%) were reduced (Fig. 2B).

These results prove our hypothesis that amount of phospholipids were reduced under P-starved condition $(0.05 \mathrm{~g} / \mathrm{l} \mathrm{P})$ while the amount of TAG was increased due to the diversion of CDP-DG pathway of phospholipids synthesis towards de novo TAG biosynthesis pathway as shown in Fig. 3 and confirmed by TLCdensitometry. It has also been studied previously that the content of TAG was increased from $6.5 \%$ up to $39.3 \%$ of total lipids while the phospholipid content was reduced in the phosphate-starved Arabidopsis thaliana cells whereas the synthesis of galactolipids compensates for the decrease in phosphatidylcholine (PC) under phosphate limited condition [29]. Earlier, It was reported that phosphate limitation causes the change of membrane phospholipids into non-phosphorus betaine lipids in photosynthetic bacteria, Rhodobacter sphaeroides [30] and, thus, represents an effective phosphate-conserving mechanism. The strategy to increase the lipid accumulation under $\mathrm{P}$ limitation is not only compatible with yeast species but also, several algae species also accumulate high lipid content under $\mathrm{P}$ limitation (high $\mathrm{C} / \mathrm{P}$ ratio in medium) e.g. Isochrysis galbana U4 accumulated almost 50\% lipid content under P-starved condition [52].

The other oleaginous yeast Rhodosporidium toruloides Y4 also produced higher amount of lipids under P-limited condition in the growth medium [45]. Under the phosphate-limited condition, C. utilis synthesized more intracellular non-polar lipid content but 
polar lipid remained relatively constant [53]. It has been suggested already that under the N-limited condition, the batch culture of $R$. glutinis showed meager growth in wet biomass and totally inhibits cell divisions on $\mathrm{N}$ consumption [54]. However, the condition was completely different under phosphate exhaustion condition where the cells showed exponential growth with increased lipidfree biomass.

Interestingly, the medium containing synchronized nitrogen and phosphorus limitations had $7.54 \pm 0.54 \mathrm{~g} / \mathrm{l}$ cell dry weight and $4.65 \pm 0.67 \mathrm{~g} / \mathrm{l}$ lipid yield along with $13-14 \%$ higher lipid content $(60.34 \pm 0.69 \%)$ than grown under the single limitation of $\mathrm{N}$ or $\mathrm{P}$ (Table 1). TLC of synchronized nutrient limitations showed highest amount of TAG $(87.14 \%$ in comparison with normal condition of GSM) with no PE and reduced amount of PC (98.36\%) in lane 7 (Fig. 2B). Sterols (St) were also absent which enhance the purity of biodiesel produced. It suggests that dual limitation of $\mathrm{N}$ and $\mathrm{P}$ causes diversion of metabolic flux from CDP-DG pathway of phospholipids (PI, PC and PE) synthesis toward that of TAG biosynthesis. This will ease TAG production without even creating mutants or inhibitors in the specific pathway to boost de novo TAG biosynthesis. These results are also comparable with the recent research work done by Bellou et al. on Y. lipolytica grown under the double limitation of nitrogen and magnesium [55]. The double limitation of nitrogen and magnesium support the lipid accumulation (47.5\% $\mathrm{w} / \mathrm{w}$ ) in this yeast and synthesize $12.2 \mathrm{~g} / \mathrm{l}$ cell dry weight and $5.8 \mathrm{~g} / \mathrm{l}$ lipid yield respectively when glucose was provided as carbon substrate [55].

Furthermore, the extension of cultivation period after glucose depletion from the medium was carried out to examine the effect of nutrient limitation on lipid biodegradation. In the case of $\mathrm{N}$ limitation $(1 \mathrm{~g} / \mathrm{l})$, the lipid content was reported to slightly decrease from $48.64 \%$ to $48.32 \%$ when culture was cultivated from 144 h to $240 \mathrm{~h}$, while at $0.1 \mathrm{~g} / \mathrm{l} \mathrm{N}$ the lipid content was decreased from $59.69 \%$ to $58.69 \%$ (Fig. 1). These results showed that $\mathrm{N}$ limitation promotes lipid degradation after glucose depletion from the medium. Interestingly, the lipid content was constant at both Pstarved condition $(0.1 \mathrm{~g} / \mathrm{l}$ and $0.05 \mathrm{~g} / \mathrm{l})$ after the extended growth period. While under synchronized limitation of $\mathrm{N}$ and $\mathrm{P}$, the biodegradation of lipid was observed and the lipid content was slightly changed from $61.71 \%$ to $61.36 \%$ after glucose exhaustion from the medium (from $168 \mathrm{~h}$ to $240 \mathrm{~h}$ ).

\subsection{Morphological changes during the nitrogen and phosphorus limitation}

The TAG accumulation in $\mathrm{N}$ and P-limited conditions were evaluated by morphological and structural variations in lipid droplet (LD) formation of yeast cellular compartment. The results of average variation in cell size and lipid droplets were statistically verified and presented in Fig. 4A and B. Maximum lipid droplets size $(5.62 \pm 0.28 \mu \mathrm{m})$ in $R$. kratochvilovae HIMPA1 were observed when cells were grown under combination of both $\mathrm{N}$ and $\mathrm{P}$ limitations in the medium, which is comparable to lipid droplets size of $\mathrm{N}$ limitation $(1 \mathrm{~g} / \mathrm{l} \mathrm{N} ; 4.32 \pm 0.64 \mu \mathrm{m}$ and $0.1 \mathrm{~g} / \mathrm{l} \mathrm{N} ; 4.68 \pm 0.21 \mu \mathrm{m})$ and $\mathrm{P}$ limitation $(0.1 \mathrm{~g} / \mathrm{l} \mathrm{P} ; 3.91 \pm 0.32 \mu \mathrm{m}$ and $0.05 \mathrm{~g} / \mathrm{l} \mathrm{P}$; $3.96 \pm 0.19 \mu \mathrm{m})$ alone provided to the yeast cells. The results obtained shows a direct correlation between lipid droplet size with the TAG accumulating ability of $R$. kratochvilovae HIMPA1 on consumption of nutritional variation of $\mathrm{N}$ and $\mathrm{P}$ (Fig. $4 \mathrm{~A}$ and $\mathrm{B}$ ) as the dye (BODIPY) stains TAG specifically.

In $\mathrm{N}$-limited condition, the perfectly round LD is surrounded by distinct tough phospholipid layer (Fig. 4B, lane 2 and 3) while it seems to be little diffused and leaky as in lane 4 and 5 (Fig. 4B) of Plimited condition. Furthermore, lack of phospholipid synthesis clearly disrupts the distinct round LD into diffused and irregular shaped LD lacking membrane layer in synchronized limitation of $\mathrm{N}$ and P. In this case the TAG storage in round LDs coalesced into an irregular multilobular large mass without a distinct LD cover with enhanced TAG content per unit cell as compare to the normal $\mathrm{N}$ and $\mathrm{P}$ condition (5 $\mathrm{g} / \mathrm{l} \mathrm{N}$ and $1 \mathrm{~g} / \mathrm{l} \mathrm{P}$ ).

TAG is not appropriate for membrane constituents as they are the neutral lipids and serves mainly as an energy source. Biogenesis of LD in the cellular compartment defined by two distinct models 'lensing model' and the 'bicelle formation model'. In lensing model, LD bud off from ER through the help of only outer leaflet while in bicelle formation model, monolayer of phospholipids form over LD with the help of both leaflets of ER. This monolayer contains PC, PI, and PE [56,57]. One more possibility of LD formation is secretory vesicle model in which TAG are filled in secretory vesicles [58] (Fig. 3). The data from the morphological studies of LD in $\mathrm{N}$ and $\mathrm{P}$ synchronized limitation supports the secretory vesicle model as the LD coalesce into one multilobular mass similar to secretory vesicles coalesces with in outer cell membrane during secretion process.

\subsection{Effect of nutritional stress conditions on fatty acid profile and biodiesel properties}

Effect of nitrogen and phosphorus limitation on fatty acid profile of $R$. kratochvilovae HIMPA1 is represented in Table 4. It has been already reported that $R$. kratochvilovae HIMPA1 grown on control (GSM) containing optimum $5 \mathrm{~g} / \mathrm{l} \mathrm{N}$ and $1 \mathrm{~g} / \mathrm{l} \mathrm{P}$, synthesized mainly myristic acid $\left(C_{14: 0}\right) 4.24 \%$, palmitic acid $\left(C_{16: 0}\right) 34.79 \%$, stearic acid $\left(\mathrm{C}_{18: 0}\right) 21.32 \%$, oleic acid $\left(\mathrm{C}_{18: 1}\right) 23.15 \%$, along with $2.23 \%$ linoleic acid $\left(\mathrm{C}_{18: 2}\right)$ [32]. The data showed that nitrogen limitation $(0.1 \mathrm{~g} / \mathrm{l} \mathrm{N})$ imparts the increment of mono-unsaturated fatty acids (MUFA) from $23.15 \pm 0.53 \%$ to $75.79 \pm 0.64 \%$ while the amount of saturated fatty acid (SFA, from $63.35 \%$ to $12.43 \%$ ) were reduced from that obtained with optimum amount of $\mathrm{N}(5 \mathrm{~g} / \mathrm{l} \mathrm{N})$ as shown in Table 4. The $\mathrm{P}$ limitation affects the fatty acids content in a similar manner. The amount of MUFA was increased from $23.15 \%$ to $66.79 \%$ while SFA content was decreased from $63.35 \%$ to $28.52 \%$ when the yeast cells grown in P-starved condition (0.05 g/l P). However, a significant increment in oleic acid $\left(\mathrm{C}_{18: 1,81.52 \%)}\right.$ was observed when both nutrients $(0.1 \mathrm{~g} / 1 \mathrm{~N}$ and $0.05 \mathrm{~g} / 1 \mathrm{P})$ were in limited condition together. It has been earlier reported that the amount of linoleic acid $\left(C_{18: 2}\right)$ present in high quantity during the lag phase of a growth period that incorporated in the cell membrane while the amount of stearic acid $\left(C_{18: 0}\right)$ and oleic acid $\left(C_{18: 1}\right)$ increased in stationary phase or lipid accumulating phase. Later on, $\Delta 9$ desaturase converted $C_{18: 0}$ into $C_{18: 1}$ by adding double-bond [59]. Desaturation in the later stage of growth ensues by an oxidative process that requires oxygen, NADH, NADPH and substrate [60]. This process prevents the accumulation of reactive oxygen species under stress condition. Various researchers previously described that the amount of MUFA was increased by unsaturated fatty acid mutants (USFA) of A. curvature with mutagenic treatment [61] or by using sterculia oil as $\Delta 9$ desaturase inhibitor [62] that block the conversion of stearic $\left(C_{18: 0}\right)$ to oleic acid $\left(C_{18: 1}\right)$. The fatty acid profile of oleaginous yeast can be altered according to provided medium e.g. Y. lipolytica ACA-DC 50109 showed enhanced intracellular $C_{18: 0}$ when cultivated on saturated fatty substrates and desired cocoa butter substitute was obtained after adding donor of $\mathrm{C}_{18: 1}$ as a co-substrate in the provided medium [15]. In another example, this strain synthesizes intracellular fatty acids similar to cocoa butter when grown on mixtures of stearin and biodiesel byproducts glycerol [24].

The conversion of total extracted lipid into FAME confirmed complete conversion (97.33\%) of TAG by TLC (Fig. 5, lane 3-7) is demonstrated in TLC chromatogram (lane 3-7). However, 91.12\% TAG conversion is reported in Fig. 5, lane 2. In the FAME profile, the 
A

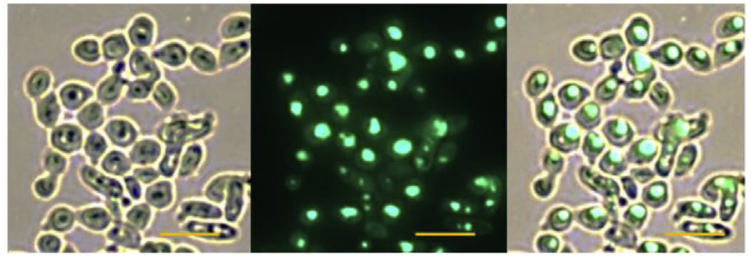

(A) $5 g / 1 \mathrm{~N}$ and $1 \mathrm{~g} / \mathrm{l} \mathrm{P}$

Cell size $5.53 \pm 0.31 \mu \mathrm{m}$ LD size $2.38 \pm 0.52 \mu \mathrm{m}$

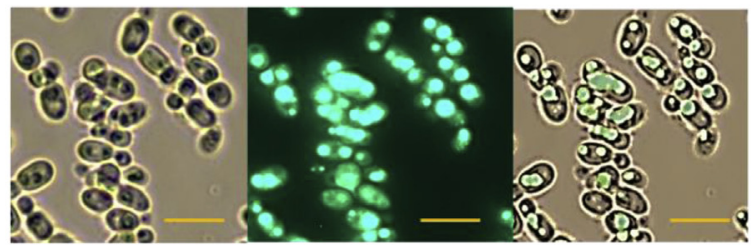

(B) $1 \mathrm{~g} / \mathrm{l} \mathrm{N}$ and $1 \mathrm{~g} / \mathrm{l} \mathrm{P}$

Cell size $5.98 \pm 0.23 \mu \mathrm{m}$

LD size $4.32 \pm 0.64 \mu \mathrm{m}$

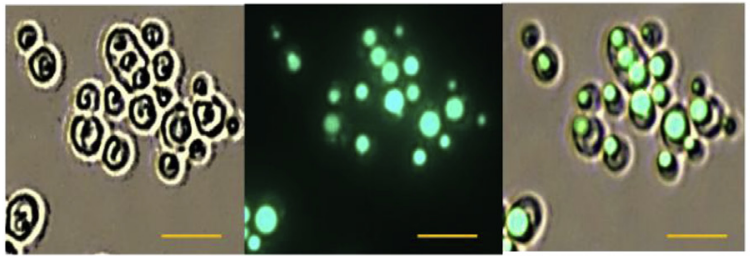

(C) $0.1 \mathrm{~g} / \mathrm{N}$ and $1 \mathrm{~g} / \mathrm{P}$
Cell size $6.12 \pm 0.37 \mu \mathrm{m}$

LD size $4.68 \pm 0.21 \mu \mathrm{m}$

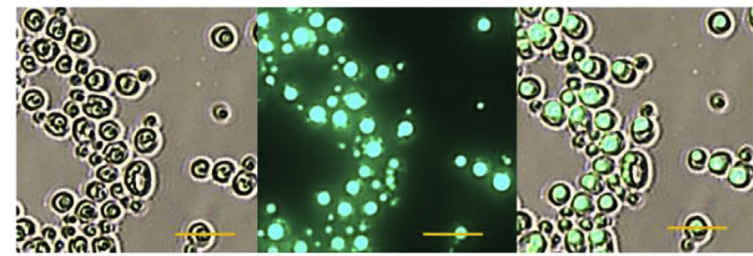

(D) $5 \mathrm{~g} / 1 \mathrm{~N}$ and $0.1 \mathrm{~g} / 1 \mathrm{P}$

Cell size $5.34 \pm 0.27 \mu \mathrm{m}$ LD size $3.91 \pm 0.32 \mu \mathrm{m}$

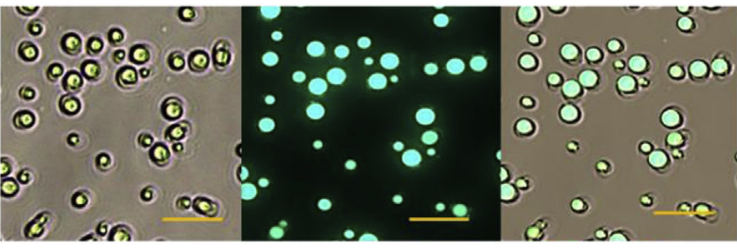

(E) $5 \mathrm{~g} / 1 \mathrm{~N}$ and $0.05 \mathrm{~g} / \mathrm{/P}$

Cell size $5.25 \pm 0.29 \mu \mathrm{m}$

LD size $3.96 \pm 0.19 \mu \mathrm{m}$

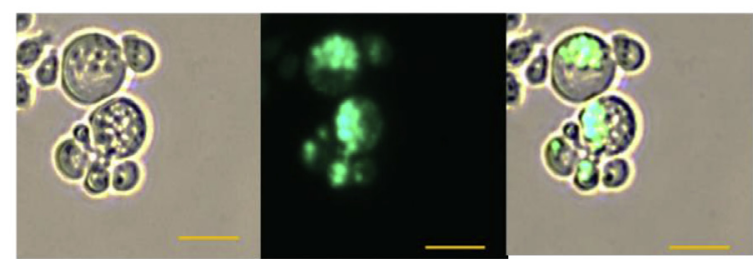

(F) $0.1 \mathrm{~g} / \mathbf{l} \mathbf{N}$ and $\mathbf{0 . 0 5 g} / \mathbf{l} \mathbf{P} \quad$ Cell size $6.76 \pm 0.39 \mu \mathrm{m}$ LD size $5.62 \pm 0.28 \mu \mathrm{m}$

B

Cell size and Lipid droplets size $(\mu \mathrm{m})$

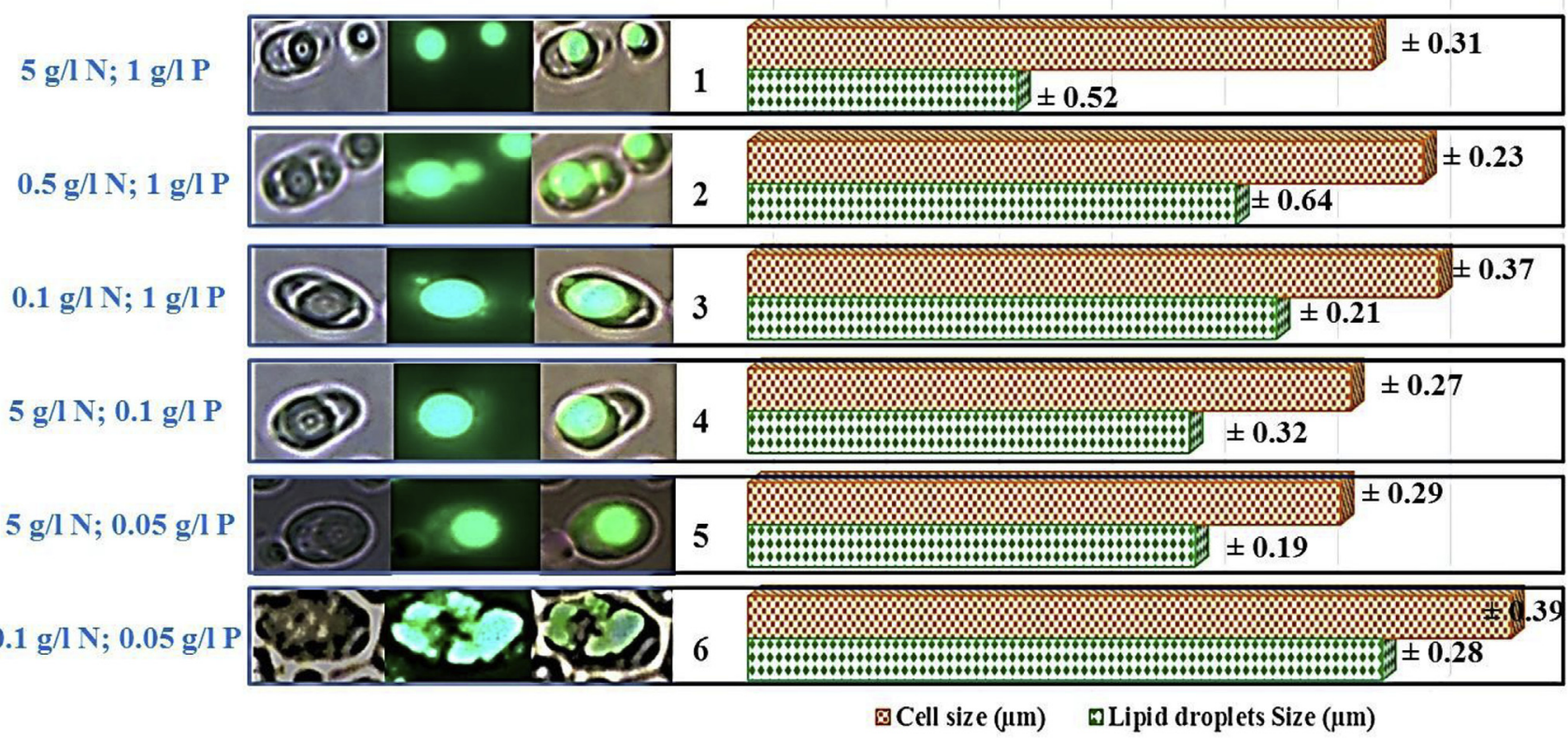

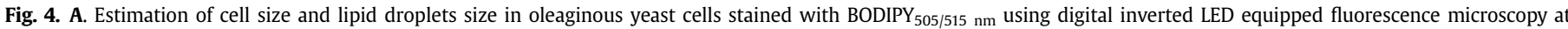

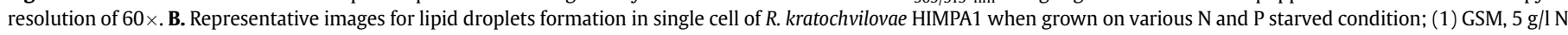

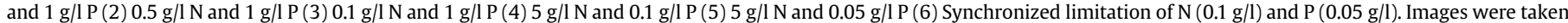
when cells achieved its stationary phase using fluorescence microscopy of live cells stained with BODIPY $505 / 515 \mathrm{~nm}$. 
Table 4

Fatty acid methyl ester profiles of oleaginous yeast (OY) grown in various nutrient limited condition.

\begin{tabular}{|c|c|c|c|c|c|c|c|}
\hline \multicolumn{2}{|c|}{ FAME composition (\%) } & \multicolumn{6}{|c|}{ Cultivation medium containing ( $\mathrm{N}$ and $\mathrm{P}$ ) } \\
\hline & & $5 \mathrm{~g} / \mathrm{l} \mathrm{N}, 1 \mathrm{~g} / \mathrm{l} \mathrm{P}$ & $1 \mathrm{~g} / \mathrm{l} \mathrm{N}, 1 \mathrm{~g} / \mathrm{l} \mathrm{P}$ & $0.1 \mathrm{~g} / \mathrm{l} \mathrm{N}, 1 \mathrm{~g} / \mathrm{l} \mathrm{P}$ & $5 \mathrm{~g} / \mathrm{l} \mathrm{N}, 0.1 \mathrm{~g} / \mathrm{l}$ & $5 \mathrm{~g} / \mathrm{l} \mathrm{N}, 0.05 \mathrm{~g} / \mathrm{l}$ & $0.1 \mathrm{~g} / \mathrm{l} \mathrm{N}, 0.05 \mathrm{~g} / \mathrm{l}$ \\
\hline \multirow[t]{6}{*}{ SFA* $^{*}$} & Lauric acid methyl ester $\left(\mathrm{C}_{12: 0}\right)$ & nd & nd & nd & nd & nd & nd \\
\hline & Myristic acid methyl ester $\left(C_{14: 0}\right)$ & $4.24 \pm 0.23$ & $0.91 \pm 0.43$ & nd & $0.19 \pm 0.31$ & nd & nd \\
\hline & Palmitic acid methyl ester $\left(C_{16: 0}\right)$ & $34.79 \pm 0.34$ & $14.64 \pm 0.12$ & $9.1 \pm 0.13$ & $18.24 \pm 0.34$ & $7.8 \pm 0.29$ & $8.63 \pm 0.27$ \\
\hline & Margaric acid methyl ester $\left(C_{17: 0}\right)$ & nd & $0.91 \pm 0.51$ & nd & $0.93 \pm 0.41$ & $1.34 \pm 0.67$ & nd \\
\hline & Stearic acid methyl ester $\left(C_{18: 0}\right)$ & $21.32 \pm 0.11$ & $8.37 \pm 0.87$ & $3.33 \pm 0.63$ & $17.6 \pm 0.54$ & $10.36 \pm 0.59$ & $1.54 \pm 0.56$ \\
\hline & Arachidic acid methyl ester $\left(C_{20: 0}\right)$ & nd & nd & nd & $0.24 \pm 0.47$ & nd & nd \\
\hline MUFA $^{* *}$ & Oleic acid methyl ester $\left(C_{18: 1}\right)$ & $23.15 \pm 0.53$ & $67.27 \pm 0.75$ & $75.79 \pm 0.64$ & $48.9 \pm 0.81$ & $66.79 \pm 0.21$ & $81.52 \pm 0.53$ \\
\hline PUFA*** & $\begin{array}{l}\text { Linoleic acid methyl ester }\left(C_{18: 2}\right) \\
\alpha \text {-Linolenic acid methyl ester }\left(C_{18: 3}\right)\end{array}$ & $\begin{array}{l}2.23 \pm 0.76 \\
\text { nd }\end{array}$ & $\begin{array}{l}8.38 \pm 0.91 \\
\text { nd }\end{array}$ & $\begin{array}{l}10.49 \pm 0.73 \\
\text { nd }\end{array}$ & $\begin{array}{l}13.35 \pm 0.61 \\
\text { nd }\end{array}$ & $\begin{array}{l}10.48 \pm 0.43 \\
\text { nd }\end{array}$ & $\begin{array}{l}7.98 \pm 0.21 \\
\text { nd }\end{array}$ \\
\hline
\end{tabular}

SFA* Saturated fatty acids.

MUFA** Monounsaturated fatty acids.

PUFA $^{* * *}$ Polyunsaturated fatty acids.

(A)

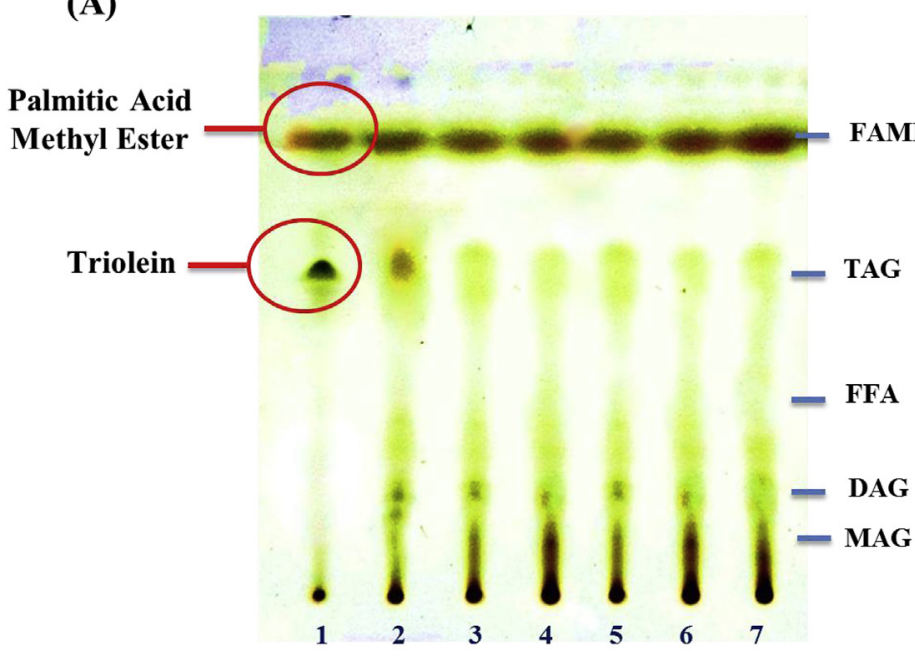

(B)

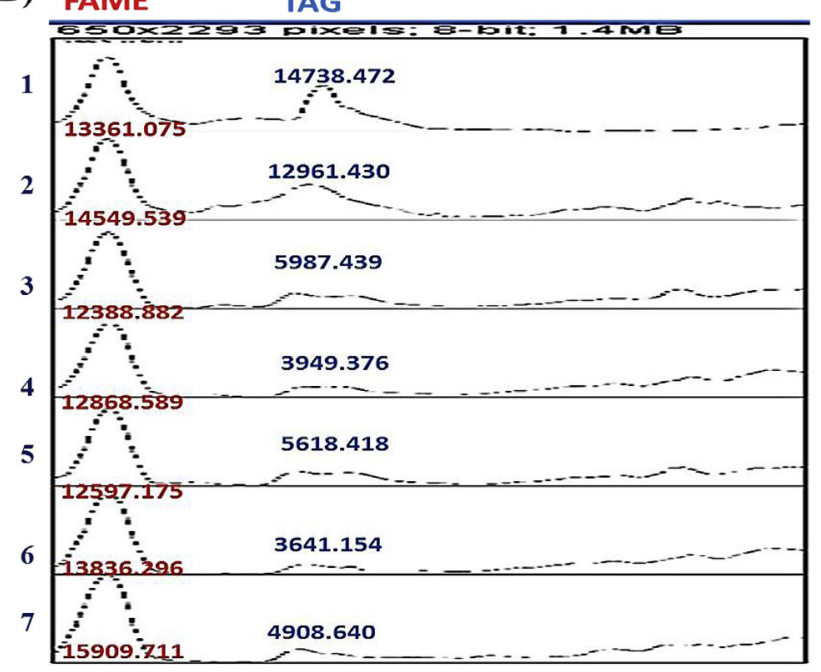

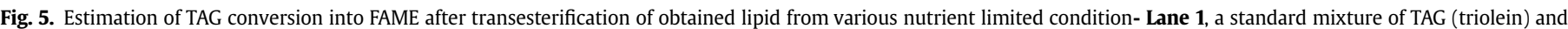

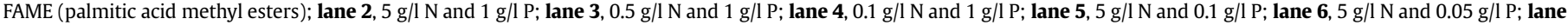
7, synchronized limitation of $\mathrm{N}(0.1 \mathrm{~g} / \mathrm{l})$ and $\mathrm{P}(0.05 \mathrm{~g} / \mathrm{l})$.

degree of unsaturation and fatty acids chain length are the two main features that determine the fuel properties. The empirical formulas were designed to explain the biodiesel properties of FAME obtained after $R$. kratochvilovae HIMPA1 was grown in various $\mathrm{N}$ and $\mathrm{P}$ limitation conditions and various important biodiesel properties such cetane number $(\mathrm{CN})$, degree of unsaturation (DU), iodine value (IV), cold filter plugging point (CFPP), density (D), kinematic viscosity (KV), long chain saturation factor (LCSF), high heating value (HHV)/calorific value, saponification value (SV), and oxidative stability (OS) were evaluated as per ASTM D6751 (United States) and EN 14214 (European Union) fuel standards. FAME profile obtained after transesterification of extracted lipid directly influences the quality of biodiesel. The $\mathrm{N}$ and P-limited condition affect the fatty acids profiles as under $\mathrm{N}$-limited conditions, high quantity of MUFA (monounsaturated fatty acids) were obtained ( $1 \mathrm{~g} / \mathrm{l} \mathrm{N}, 67.27 \%$ and $0.1 \mathrm{~g} / \mathrm{l} \mathrm{N}, 75.79 \%$ ) whereas under P limitation the quantity of MUFA also raised $(0.1 \mathrm{~g} / 1 \mathrm{P}, 48.9 \%$ and $0.05 \mathrm{~g} / \mathrm{l} \mathrm{P}$ $66.79 \%$ ) as compared to normal condition of $\mathrm{N}$ and $\mathrm{P}$. Moreover, the combination of both nutrients limitation contributed high quantity of MUFA (0.1 g/l N and $0.05 \mathrm{~g} / 1 \mathrm{P} ; 81.52 \%)$ that causes the enhancement of cold flow plugging properties $\left(-10.897^{\circ} \mathrm{C}\right)$. High SFA (saturated fatty acids) present in FAME mitigate the biodiesel to auto-oxidation and thereby increasing its shelf-life while UFA (unsaturated fatty acids) quantities determine its cold flow plugging properties. Therefore, it is necessary to control the fuel properties with the optimum ratio of SFA to UFA. The important property of biodiesel to perform at low temperature is determined by the degree of unsaturation. The data showed that degree of unsaturation was increased from $27.61 \%$ to $99.77 \%$ in N-starved condition $(0.1 \mathrm{~g} / \mathrm{l} \mathrm{N})$ while $87.67 \%$ increment was reported in Pstarved condition $(0.05 \mathrm{~g} / \mathrm{l} \mathrm{P})$ Table 5 . Fatty acid unsaturation is also depicted by iodine value (IV). Biodiesel obtained from R. kratochvilovae HIMPA1 grown under N $(0.1 \mathrm{~g} / \mathrm{l} \mathrm{N})$ and $\mathrm{P}(0.05 \mathrm{~g} / \mathrm{l})$ limited condition showed 83.1616 and $75.3527 \mathrm{gI}_{2} / 100 \mathrm{~g}$ of iodine value, respectively while in normal condition of $\mathrm{N}$ and $\mathrm{P}(5 \mathrm{~g} / \mathrm{l}$ and $1 \mathrm{~g} / \mathrm{l}$ ), it was $23.7184 \mathrm{gI}_{2} / 100 \mathrm{~g}$. The experimental value of IV of different oil samples obtained from oleaginous yeast grown in GSM containing ( $5 \mathrm{~g} / 1 \mathrm{~N}$ and $1 \mathrm{~g} / \mathrm{l} \mathrm{P}$ ) control; $(1 \mathrm{~g} / 1 \mathrm{~N}$ and $1 \mathrm{~g} / \mathrm{l} \mathrm{P} ; 0.1 \mathrm{~g} / \mathrm{l} \mathrm{N}$ and $1 \mathrm{~g} / \mathrm{l} \mathrm{P}$ ) nitrogen limitation; ( $5 \mathrm{~g} / \mathrm{l} \mathrm{N}$ and $0.1 \mathrm{~g} / \mathrm{l} \mathrm{P} ; 5 \mathrm{~g} / \mathrm{l} \mathrm{N}$ and $0.05 \mathrm{~g} / \mathrm{l} \mathrm{P}$ ) phosphorus limitation; (0.1 g/l N and $0.05 \mathrm{~g} / \mathrm{l} \mathrm{P})$ synchronized limitation of $\mathrm{N}$ and $\mathrm{P}$ were 20.13, 11.29, 74.65, 59.65, $69.43,78.32 \mathrm{gI}_{2} / 100 \mathrm{~g}$ respectively. European Union standard (EN 14214 ) has set a limit of $120 \mathrm{~g} \mathrm{I}_{2} / 100 \mathrm{~g}$ which excludes sunflower, soya bean, grape seed oil as potential feedstocks for biodiesel production. As reported in the literature that high iodine value results in polymerization of glycerides and on heating it has the problem of gum formation $[63,64]$. Another important biodiesel property the saponification value (SV) is used to measure the 
A. Patel et al. / Energy 139 (2017) 962-974

Table 5

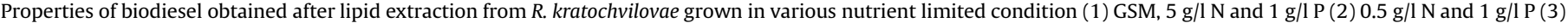
$0.1 \mathrm{~g} / \mathrm{l} \mathrm{N}$ and $1 \mathrm{~g} / \mathrm{l} \mathrm{P}(4) 5 \mathrm{~g} / \mathrm{l} \mathrm{N}$ and $0.1 \mathrm{~g} / \mathrm{l} \mathrm{P}(5) 5 \mathrm{~g} / \mathrm{l} \mathrm{N}$ and $0.05 \mathrm{~g} / \mathrm{l} \mathrm{P}(6)$ Synchronized limitation of N (0.1 g/l) and P (0.05 g/l).

\begin{tabular}{|c|c|c|c|c|c|c|c|c|}
\hline \multirow{2}{*}{$\begin{array}{l}\text { Quality parameters } \\
\text { of biodiesel }\end{array}$} & \multirow{2}{*}{$\begin{array}{l}5 \mathrm{~g} / \mathrm{l} \mathrm{N} \text { and } \\
1 \mathrm{~g} / \mathrm{l}\end{array}$} & \multirow{2}{*}{$\begin{array}{l}1 \mathrm{~g} / \mathrm{l} \mathrm{N} \text { and } \\
1 \mathrm{~g} / \mathrm{l} \mathrm{P}\end{array}$} & \multirow{2}{*}{$\begin{array}{l}0.1 \mathrm{~g} / \mathrm{l} \mathrm{N} \text { and } \\
1 \mathrm{~g} / \mathrm{l} \mathrm{P}\end{array}$} & \multirow{2}{*}{$\begin{array}{l}5 \mathrm{~g} / \mathrm{l} \mathrm{N} \text { and } \\
0.1 \mathrm{~g} / \mathrm{l} \mathrm{P}\end{array}$} & \multirow{2}{*}{$\begin{array}{l}5 \mathrm{~g} / \mathrm{l} \mathrm{N} \text { and } \\
0.05 \mathrm{~g} / \mathrm{l} \mathrm{P}\end{array}$} & \multirow{2}{*}{$\begin{array}{l}0.1 \mathrm{~g} / \mathrm{l} \mathrm{N} \text { and } \\
0.05 \mathrm{~g} / \mathrm{l} \mathrm{P}\end{array}$} & \multicolumn{2}{|c|}{ Standard fuel parameters } \\
\hline & & & & & & & ASTM D6751-02 & EN 14214 \\
\hline SV (mg KOH) & 160.266 & 196.806 & 191.141 & 191.054 & 183.65 & 190.22 & - & - \\
\hline $\mathrm{IV}\left(\mathrm{g} \mathrm{I}_{2} / 100 \mathrm{~g}\right)$ & 23.7184 & 14.4797 & 83.1616 & 65.0288 & 75.3527 & 83.7415 & - & $120\left(\max ^{a}\right)$ \\
\hline $\mathrm{CN}$ & 74.3076 & 70.3406 & 53.6486 & 58.2855 & 56.8046 & 53.639 & $47 \mathrm{~min}$ & $51(\min )$ \\
\hline DU (\% wt) & 27.61 & 16.76 & 96.77 & 75.6 & 87.67 & 97.48 & - & - \\
\hline LCSF (\% wt) & 14.139 & 5.649 & 2.575 & 10.864 & 5.96 & 1.633 & - & - \\
\hline CFPP $\left({ }^{\circ} \mathrm{C}\right)$ & 31.836 & 2.82563 & -7.67823 & 20.6453 & 3.88832 & -10.897 & - & $\leq 5 / \leq-20$ \\
\hline $\mathrm{HHV}(\mathrm{MJ} / \mathrm{kg})$ & 42.5033 & 41.1438 & 40.3458 & 40.6214 & 40.7701 & 40.3748 & - & - \\
\hline $\mathrm{KV}\left(\mathrm{mm}^{2} / \mathrm{s}\right)$ & 4.52329 & 4.31376 & 4.60324 & 4.93235 & 4.60324 & 4.52329 & $1.9-6.0$ & $3.5-5.0$ \\
\hline Density $\left(\mathrm{g} / \mathrm{cm}^{3}\right)$ & 0.872103 & 0.868772 & 0.870393 & 0.868883 & 0.870393 & 0.872103 & - & $0.86-0.90$ \\
\hline Oxidative Stability (h) & 55.4737 & 16.6632 & 13.8326 & 11.4242 & 13.8433 & 17.3686 & - & $\geq 6$ \\
\hline
\end{tabular}

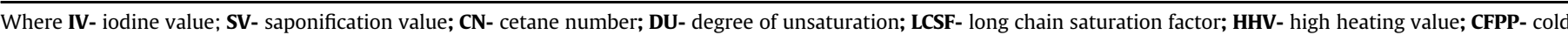
filter plugging point; KV- kinematic viscosity.

-No standard limit designated by ASTM D6751-02 and EN 14214 biodiesel standards.

a Maximum value set.

molecular weight or chain length of fatty acids and defined by the amount of $\mathrm{KOH}$ in $\mathrm{mg}$ required to saponify one $\mathrm{g}$ of fat under a specific condition [65]. SV of oil obtained from $R$. kratochvilovae grown under $\mathrm{N}(0.1 \mathrm{~g} / \mathrm{l} \mathrm{N})$ and $\mathrm{P}(0.05 \mathrm{~g} / \mathrm{l} \mathrm{P})$ starved condition showed high value (190.22 $\mathrm{mg} \mathrm{KOH}$ and $183.65 \mathrm{mg} \mathrm{KOH}$, respectively) than $160 \mathrm{mg} \mathrm{KOH}$ as obtained under optimum condition of ( $5 \mathrm{~g} / \mathrm{l}) \mathrm{N}$ and $(1 \mathrm{~g} / \mathrm{l}) \mathrm{P}$ (Table 5). The experimental value of SV of different oil samples obtained from oleaginous yeast grown in GSM containing ( $5 \mathrm{~g} / \mathrm{l} \mathrm{N}$ and $1 \mathrm{~g} / \mathrm{l} \mathrm{P}$ ) control; ( $1 \mathrm{~g} / \mathrm{l} \mathrm{N}$ and $1 \mathrm{~g} / \mathrm{l} \mathrm{P} ; 0.1 \mathrm{~g} / \mathrm{l} \mathrm{N}$ and $1 \mathrm{~g} / \mathrm{l} \mathrm{P}$ ) nitrogen limitation; (5 g/l $\mathrm{N}$ and $0.1 \mathrm{~g} / \mathrm{l} \mathrm{P} ; 5 \mathrm{~g} / \mathrm{l} \mathrm{N}$ and $0.05 \mathrm{~g} / \mathrm{l} \mathrm{P}$ ) phosphorus limitation; $(0.1 \mathrm{~g} / \mathrm{l} \mathrm{N}$ and $0.05 \mathrm{~g} / \mathrm{l} \mathrm{P})$ synchronized limitation of $\mathrm{N}$ and $\mathrm{P}$ were 158, 189, 178, 179, 163 and $178 \mathrm{mg} \mathrm{KOH}$ respectively. The obtained SV value were practically similar with the value obtained from empirical formula. The flow of any type of fuel in a conventional engine is defined by their density and viscosity. Under $\mathrm{N}$ and P-starved condition the kinematic viscosity were $4.60324 \mathrm{~mm}^{2} / \mathrm{s}$ and $4.60324 \mathrm{~mm}^{2} / \mathrm{s}$ respectively, while under synchronized nutrient limited condition $(0.1 \mathrm{~g} / 1 \mathrm{~N}$ and $0.05 \mathrm{~g} /$ $\mathrm{l} \mathrm{P)} \mathrm{the} \mathrm{KV} \mathrm{was} 4.52329 \mathrm{~mm}^{2} / \mathrm{s}$ that show similar result under normal condition of ( $5 \mathrm{~g} / 1 \mathrm{~N}$ and $1 \mathrm{~g} / \mathrm{l} \mathrm{P}$ ). The ASTM D6751 viscosity specification of $1.9-6.0 \mathrm{~mm}^{2} / \mathrm{s}$ is satisfied by these results and $\mathrm{KV}$ majorly affects the injection into the engine because higher viscosity leads to larger droplet sizes, poorer vaporization, and narrower injection spray angle [66]. Density is also an important parameter of biodiesel that is correlated with another parameter for engine performance such as cetane number and heating value. Fuel injection property is totally dependent on its density as higher or lesser volume of fuel is injected. It affects the pumping of fuel by its volume not by mass. It can be defined as the mass of a substrate divided by its volume or weight per unit volume. Denser oil has more energy and biodiesel is usually having higher density than petroleum diesel. The density of the fuel is correlated with other properties such as HHV, viscosity, cetane number which depends on temperature, water content, and the presence of free fatty acid content in FAME. The data obtained for density after synchronized nutrient limitation of $\mathrm{N}$ and $\mathrm{P}$ showed $0.872103 \mathrm{~g} / \mathrm{cm}^{3}$ that was similar with data obtained in the normal condition of $\mathrm{N}$ and $\mathrm{P}$ $\left(0.872103 \mathrm{~g} / \mathrm{cm}^{3}\right)$. Oxidative stability is another essential fuel property which gets influenced by the presence of high amount of UFA in biodiesel. Increasing the number of double bonds in UFA leads to autoxidation. The data showed that without limitations of nutrients in the medium, the biodiesel obtained was more stable $(55.4737 \mathrm{~h})$ than the limitations of $\mathrm{N}(1 \mathrm{~g} \mathrm{l} \mathrm{N}, 16.6632 \mathrm{~h}$ and $0.1 \mathrm{~g} / \mathrm{l} \mathrm{N}$, $13.8326 \mathrm{~h})$ and limitations of $\mathrm{P}(0.1 \mathrm{~g} / \mathrm{l} \mathrm{P}, 11.4242 \mathrm{~h}$ and $0.05 \mathrm{~g} / \mathrm{l} \mathrm{P}$, $13.8433 \mathrm{~h}$ ). Cetane number $(\mathrm{CN})$ is again the significant property of fuel that decides the ignition characteristics of fuel i.e. how any fuel got ignite and combust. It affects the various parameters of engine performance such as noise, emissions of $\mathrm{CO}$ and stability. Higher $\mathrm{CN}$ imparts the better ignition of biodiesel than the conventional diesel fuel ensuring better cold start behavior, smooth engine run and complete combustion leading to reduced gaseous and particulate emissions $[66,67]$. The data showed in this study suggest that the medium containing sufficient quantity of $\mathrm{N}$ and $\mathrm{P}$ (without any limitations) has higher $\mathrm{CN}$ (74.3076) than $\mathrm{CN}$ obtained after $\mathrm{N}$ and P-limited condition (53.6484 and 52.639 respectively). The data also indicate that the biodiesel obtained after normal and nutrient limited condition as listed in Table 1 satisfy the $\mathrm{CN}$ limit describe by both ASTM D6751-02 and EN 14214 standard. Cetane number has both its lower and higher limits as lower cetane number of biodiesel causes difficulty of engine starting in cold environmental and generation of noise and pollution (emissions of hydrocarbons) without proper combustion of biodiesel while higher cetane number causes instant ignition without proper mixing of air that results in decrease in efficiency of fuel $[39,67]$. The heating energy released during the combustion of the unit value of fuels is considered as the heating value (HV) of fuels and it is also known as calorific value or heat of combustion. The elements of fuel such as $\mathrm{O}_{2}, \mathrm{H}, \mathrm{C}, \mathrm{N}$, and $\mathrm{S}$ after burning generates gaseous $\mathrm{CO}_{2}, \mathrm{NO}, \mathrm{SO}_{2}$, and water along with heat. Biodiesel has low energy content due to approximately $12 \%$ less HHV than that of diesel (39.57-41.33 MJ/ $\mathrm{kg}$ ) and consumption rate in a diesel engine is also high in order to attain similar yield as that of conventional diesel $[67,68]$. The result concluded that biodiesel obtained after synchronized $\mathrm{N}$ and $\mathrm{P}$ starved condition had $40.3748 \mathrm{MJ} / \mathrm{kg} \mathrm{HHV}$ while the value was high (42.5033 MJ $/ \mathrm{kg}$ ) under normal condition of $\mathrm{N}$ and P. From the above discussion, biodiesel properties such as oxidative stability, viscosity, cetane number and Cold filter plugging point were recorded to get influenced by the presence of high quantity of MUFA in the fatty acid profile under nutrient stress condition and we can say that FAME composition of particular biodiesel is not sufficient to be optimum with respect to all important parameters. To combat this challenge it is necessary to blend the biodiesels with two different optimum parameters.

\section{Conclusion}

In summary, $R$. kratochvilovae HIMPA1 has the ability to accumulate high levels of storage lipid enriched with monounsaturated fatty acids under certain nutrient stress conditions. Among various $\mathrm{N}$ and $\mathrm{P}$ limitation conditions, the highest lipid content $(60.34 \pm 0.69 \%)$ was obtained when both nutrients were in limited condition $(0.1 \mathrm{~g} / \mathrm{l} \mathrm{N}$ and $0.05 \mathrm{~g} / \mathrm{l} \mathrm{P})$. However, P limitation under 
nitrogen-rich condition gives high lipid content without compromising its biomass that was contrary in $\mathrm{N}$ limitation where the lipid accumulation compensates with biomass. $\mathrm{P}$ limitation also causes decrease in phospholipids (PE and PC) tremendously while increase in $78.55 \%$ TAG as depicted by TLC. An important finding of this study is the yeast cell morphology and lipid droplets size in response to change of cultivation conditions, especially in nutrient stress condition. Under synchronized limitation of $\mathrm{N}$ and $\mathrm{P}$ supersized, coalesced irregular shaped lipid lobules were formed in the cellular compartment of oleaginous yeast along with $87.14 \%$ enhanced TAG accumulation. Both $\mathrm{N}$ and $\mathrm{P}$ limitation diverts the CDP-DG pathway of phospholipids synthesis towards de novo TAG synthesis. Moreover, the accumulated lipids under these conditions were rich in MUFA that provide biodiesel having greater performance at a lower temperature (CFPP) and enhanced oxidative stability.

\section{Acknowledgement}

The present study was financially supported by DBT, Govt. of India, Bio Care Programme, DBT Sanction No. 102/IFD/SAN/3539/ 2011-2012 (Grant No.: DBT-608-BIO) and SRF to Alok Patel from UGC, India (Grant No.: 6405-35-044).

\section{Appendix A. Supplementary data}

Supplementary data related to this article can be found at http:// dx.doi.org/10.1016/j.energy.2017.08.052.

\section{References}

[1] Patel A, Arora N, Sartaj K, Pruthi V, Pruthi PA. Sustainable biodiesel production from oleaginous yeasts utilizing hydrolysates of various non-edible lignocellulosic biomasses. Renew Sustain Energy Rev 2016;62:836-55. http:/ dx.doi.org/10.1016/j.rser.2016.05.014.

[2] Sajid Z, Khan F, Zhang Y. Process simulation and life cycle analysis of biodiese production. Renew Energy 2016;85:945-52. http://dx.doi.org/10.1016 j.renene.2015.07.046

[3] Balat M, Balat H. Progress in biodiesel processing. Appl Energy 2010;87: 1815-35. http://dx.doi.org/10.1016/j.apenergy.2010.01.012.

[4] Leung DYC, $\mathrm{Wu} \mathrm{X}$, Leung MKH. A review on biodiesel production using catalyzed transesterification. Appl Energy 2010;87:1083-95. http:// dx.doi.org/10.1016/j.apenergy.2009.10.006.

[5] Huang C, Chen XX, Xiong L, Yang X, Chen XX, Ma L, et al. Microbial oil production from corncob acid hydrolysate by oleaginous yeast Trichosporon coremiiforme. Biomass Bioenergy 2013;49:273-8. http://dx.doi.org/10.1016/ j.biombioe.2012.12.023.

[6] Li Y, Zhao Z (Kent), Bai F. High-density cultivation of oleaginous yeast Rhodosporidium toruloides $\mathrm{Y} 4$ in fed-batch culture. Enzyme Microb Technol 2007;41:312-7. http://dx.doi.org/10.1016/j.enzmictec.2007.02.008.

[7] Ratledge C. Regulation of lipid accumulation in oleaginous micro-organisms. Biochem Soc Trans 2002;30:1047-50. http://dx.doi.org/10.1042/.

[8] Ageitos JM, Vallejo JA, Veiga-Crespo P, Villa TG. Oily yeasts as oleaginous cell factories. Appl Microbiol Biotechnol 2011;90:1219-27. http://dx.doi.org/ 10.1007/s00253-011-3200-z.

[9] Sitepu IR, Garay LA, Sestric R, Levin D, Block DE, German JB, et al. Oleaginous yeasts for biodiesel: current and future trends in biology and production. Biotechnol Adv 2014;32:1336-60. http://dx.doi.org/10.1016/ j.biotechadv.2014.08.003.

[10] Papanikolaou S, Aggelis G. Lipids of oleaginous yeasts. Part II: technology and potential applications. Eur J Lipid Sci Technol 2011;113:1052-73. http:// dx.doi.org/10.1002/ejlt.201100015.

[11] Patel A, Pruthi V, Singh RP, Pruthi PA. Synergistic effect of fermentable and non-fermentable carbon sources enhances TAG accumulation in oleaginous yeast Rhodosporidium kratochvilovae HIMPA1. Bioresour Technol 2015;188: 136-44. http://dx.doi.org/10.1016/j.biortech.2015.02.062.

[12] Koutinas AA, Chatzifragkou A, Kopsahelis N, Papanikolaou S, Kookos IK. Design and techno-economic evaluation of microbial oil production as renewable resource for biodiesel and oleochemical production. Fuel 2014;116:566-77. http://dx.doi.org/10.1016/j.fuel.2013.08.045.

[13] Ratledge C, Cohen Z. Microbial and algal oils: do they have a future for biodiesel or as commodity oils? Lipid Technol 2008;20:155-60. http:/ dx.doi.org/10.1002/lite.200800044.

[14] Papanikolaou S, Chevalot I, Komaitis M, Aggelis G, Marc I. Kinetic profile of the cellular lipid composition in an oleaginous Yarrowia lipolytica capable of producing a cocoa-butter substitute from industrial fats. Ant Van Leeuwenhoek 2001;80:215-24. http://dx.doi.org/10.1023/A:1013083211405.

[15] Papanikolaou S, Aggelis G. Yarrowia lipolytica: a model microorganism used for the production of tailor-made lipids. Eur J Lipid Sci Technol 2010;112: 639-54. http://dx.doi.org/10.1002/ejlt.200900197.

[16] Fakas S, Papanikolaou S, Galiotou-Panayotou M, Komaitis M, Aggelis G. Lipids of Cunninghamella echinulata with emphasis to $\gamma$-linolenic acid distribution among lipid classes. Appl Microbiol Biotechnol 2006;73:676-83. http:// dx.doi.org/10.1007/s00253-006-0506-3.

[17] Chatzifragkou A, Makri A, Belka A, Bellou S, Mavrou M, Mastoridou M, et al. Biotechnological conversions of biodiesel derived waste glycerol by yeast and fungal species. Energy 2011;36:1097-108. http://dx.doi.org/10.1016/ j.energy.2010.11.040.

[18] Soccol CR, Dalmas Neto CJ, Soccol VT, Sydney EB, da Costa ESF, Medeiros ABP, et al. Pilot scale biodiesel production from microbial oil of Rhodosporidium toruloides DEBB 5533 using sugarcane juice: performance in diesel engine and preliminary economic study. Bioresour Technol 2017;223:259-68. http:// dx.doi.org/10.1016/j.biortech.2016.10.055.

[19] Tkachenko AF, Tigunova OA, Shulga SM. Microbial lipids as a source of biofuel. Cytol Genet 2013;47:343-8. http://dx.doi.org/10.3103/S0095452713060054.

[20] Athenstaedt K, Daum G. The life cycle of neutral lipids: synthesis, storage and degradation. Cell Mol Life Sci 2006;63:1355-69. http://dx.doi.org/10.1007/ s00018-006-6016-8.

[21] Xu J, Du W, Zhao X, Liu D. Renewable microbial lipid production from Oleaginous Yeast: some surfactants greatly improved lipid production of Rhodosporidium toruloides. World J Microbiol Biotechnol 2016;32:1-9. http:/ dx.doi.org/10.1007/s11274-016-2076-6.

[22] Tchakouteu SS, Kopsahelis N, Chatzifragkou A, Kalantzi O, Stoforos NG, Koutinas AA, et al. Rhodosporidium toruloides cultivated in $\mathrm{NaCl}$-enriched glucose-based media: adaptation dynamics and lipid production. Eng Life Sci 2017;17:237-48. http://dx.doi.org/10.1002/elsc.201500125.

[23] Moustogianni A, Bellou S, Triantaphyllidou I-E, Aggelis G. Alterations in fatty acid composition of Cunninghamella echinulata lipids induced by orange essential oil. Environ Biotechnol 2014;10:1-7. http://dx.doi.org/10.14799/ ebms237.

[24] Papanikolaou S, Aggelis G. Selective uptake of fatty acids by the yeast Yarrowia lipolytica. Eur J Lipid Sci Technol 2003;105:651-5. http://dx.doi.org/10.1002/ ejlt.200300858.

[25] Papanikolaou S, Galiotou-Panayotou M, Fakas S, Komaitis M, Aggelis G. Citric acid production by Yarrowia lipolytica cultivated on olive-mill wastewaterbased media. Bioresour Technol 2008;99:2419-28. http://dx.doi.org/10.1016/ j.biortech.2007.05.005

[26] Wu S, Hu C, Jin G, Zhao X, Zhao ZK. Phosphate-limitation mediated lipid production by Rhodosporidium toruloides. Bioresour Technol 2010;101: 6124-9. http://dx.doi.org/10.1016/j.biortech.2010.02.111.

[27] Klug L, Daum G. Yeast lipid metabolism at a glance. FEMS Yeast Res 2014;14: 369-88. http://dx.doi.org/10.1111/1567-1364.12141.

[28] Ratledge C, Wynn JP. The biochemistry and molecular biology of lipid accumulation in oleaginous microorganisms. Adv Appl Microbiol 2002;51:1-51.

[29] Härtel H, Dormann P, Benning C. DGD1-independent biosynthesis of extraplastidic galactolipids after phosphate deprivation in Arabidopsis. Proc Natl Acad Sci U. S. A 2000;97:10649-54. http://dx.doi.org/10.1073/ pnas. 180320497

[30] Benning C, Huang ZH, Gage DA. Accumulation of a novel glycolipid and a betaine lipid in cells of Rhodobacter sphaeroides grown under phosphate limitation. Arch Biochem Biophys 1995;317:103-11. http://dx.doi.org/ 10.1006/abbi.1995.1141.

[31] Patel A, Sindhu DK, Arora N, Singh RP, Pruthi V, Pruthi PA. Biodiesel production from non-edible lignocellulosic biomass of Cassia fistula L. fruit pulp using oleaginous yeast Rhodosporidium kratochvilovae HIMPA1. Bioresour Technol 2015;197:91-8. http://dx.doi.org/10.1016/j.biortech.2015.08.039.

[32] Patel A, Arora N, Pruthi V, Pruthi PA. Biological treatment of pulp and paper industry effluent by oleaginous yeast integrated with production of biodiesel as sustainable transportation fuel. J Clean Prod 2017;142:2858-64. http:// dx.doi.org/10.1016/j.jclepro.2016.10.184.

[33] Zhao X, Wu S, Hu C, Wang Q, Hua Y, Zhao ZK. Lipid production from Jerusalem artichoke by Rhodosporidium toruloides Y4. J Ind Microbiol Biotechnol 2010;37:581-5. http://dx.doi.org/10.1007/s10295-010-0704-y.

[34] Yang X, Jin G, Gong Z, Shen H, Bai F, Kent Z, et al. Recycling microbial lipid production wastes to cultivate oleaginous yeasts. Bioresour Technol 2015;175:91-6. http://dx.doi.org/10.1016/j.biortech.2014.10.020.

[35] Patel A, Pravez M, Deeba F, Pruthi V, Singh RP, Pruthi PA. Boosting accumulation of neutral lipids in Rhodosporidium kratochvilovae HIMPA1 grown on hemp (Cannabis sativa Linn) seed aqueous extract as feedstock for biodiesel production. Bioresour Technol 2014;165:214-22. http://dx.doi.org/10.1016/ j.biortech.2014.03.142.

[36] Ichihara K, Fukubayashi Y. Preparation of fatty acid methyl esters for gasliquid chromatography. J Lipid Res 2010;51:635-40. http://dx.doi.org/ 10.1194/jlr.D001065.

[37] Fedosov SN, Brask J, Xu X. Analysis of biodiesel conversion using thin layer chromatography and nonlinear calibration curves. J Chromatogr A 2011;1218: 2785-92. http://dx.doi.org/10.1016/j.chroma.2011.01.067.

[38] Islam MA, Magnusson M, Brown RJ, Ayoko GA, Nabi MN, Heimann K. Microalgal species selection for biodiesel production based on fuel properties derived from fatty acid profiles. Energies 2013;6:5676-702. http://dx.doi.org/ 
10.3390/en6115676.

[39] Ramos MJ, Fernández CM, Casas A, Rodríguez L. Pérez Á. Influence of fatty acid composition of raw materials on biodiesel properties. Bioresour Technol 2009;100:261-8. http://dx.doi.org/10.1016/j.biortech.2008.06.039.

[40] Richardson JW, Outlaw JL, Allison M. The economics of microalgae oil. AgBioForum 2010;13:119-30. http://dx.doi.org/10.1002/jctb.2338.

[41] Wu H, Miao X. Biodiesel quality and biochemical changes of microalgae Chlorella pyrenoidosa and Scenedesmus obliquus in response to nitrate levels. Bioresour Technol 2014;170. http://dx.doi.org/10.1016/j.biortech.2014.08.017. Ahead of Print.

[42] AOCS. Official methods and recommended practices of the American Oil Chemists Society. fourth ed. Champaign: American Oil Chemists' Society, USA; 1992.

[43] Papanikolaou S, Aggelis G. Lipids of oleaginous yeasts. Part I: biochemistry of single cell oil production. Eur J Lipid Sci Technol 2011;113:1031-51. http:// dx.doi.org/10.1002/ejlt.201100014.

[44] Wu S, Zhao X, Shen H, Wang Q Zhao ZK. Microbial lipid production by Rhodosporidium toruloides under sulfate-limited conditions. Bioresour Technol 2011;102:1803-7. http://dx.doi.org/10.1016/j.biortech.2010.09.033.

[45] Li Y, Liu B, Zhao Z, Bai F. Optimization of culture conditions for lipid production by Rhodosporidium toruloides. Chin J Biotechnol 2006;22:650-6. http://dx.doi.org/10.1016/S1872-2075(06)60050-2.

[46] Papanikolaou S, Komaitis M, Aggelis G. Single cell oil (SCO) production by Mortierella isabellina grown on high-sugar content media. Bioresour Technol 2004;95:287-91. http://dx.doi.org/10.1016/j.biortech.2004.02.016.

[47] Hassan M, Blanc PJ, Granger L-M, Pareilleux A, Goma G. Influence of nitrogen and iron limitations on lipid production by Cryptococcus curvatus grown in batch and fed-batch culture. Process Biochem 1996;31:355-61. http:// dx.doi.org/10.1016/0032-9592(95)00077-1.

[48] Brauer MJ, Yuan J, Bennett BD, Lu W, Kimball E, Botstein D, et al. Conservation of the metabolomic response to starvation across two divergent microbes. Proc Natl Acad Sci U. S. A 2006;103:19302-7. http://dx.doi.org/10.1073/ pnas.0609508103.

[49] Rattray J, Schibeci A, Kidby D. Lipids of yeasts. Bacteriol Rev 1975;39: $197-231$.

[50] Tchakouteu SS, Chatzifragkou A, Kalantzi O, Koutinas AA, Aggelis G, Papanikolaou S. Oleaginous yeast Cryptococcus curvatus exhibits interplay between biosynthesis of intracellular sugars and lipids. Eur J Lipid Sci Technol 2015;117:657-72. http://dx.doi.org/10.1002/ejlt.201400347.

[51] El-Sheek MM, Rady AA. Effect of phosphorus starvation on growth, photosynthesis and some metabolic processes in the unicellular green alga Chlorella kessleri. Phyt Horn Austria 1995;35:139-51.

[52] Roopnarain A, Gray VM, Sym SD. Phosphorus limitation and starvation effects on cell growth and lipid accumulation in Isochrysis galbana U4 for biodiesel production. Bioresour Technol 2014;156:408-11. http://dx.doi.org/10.1016/ j.biortech.2014.01.092.

[53] Johnson V, Singh M, Saini VS, Sista VR, Yadav NK. Effect of pH on lipid accumulation by an oleaginous yeast: Rhodotorula glutinis IIP-30. World J Microbiol Biotechnol 1992;8:382-4. http://dx.doi.org/10.1007/BF01198749.

[54] Gu Pan J, Shick Rhee J. Kinetic and energetic analyses of lipid accumulation in batch culture of Rhodotorula glutinis. J Ferment Technol 1986;64:557-60. http://dx.doi.org/10.1016/0385-6380(86)90082-8.

[55] Bellou S, Triantaphyllidou I-EE, Mizerakis P, Aggelis G. High lipid accumulation in Yarrowia lipolytica cultivated under double limitation of nitrogen and magnesium. J Biotechnol 2016;234:116-26. http://dx.doi.org/10.1016/ j.jbiotec.2016.08.001.

[56] Guo Y, Cordes KR, Farese RV, Walther TC. Lipid droplets at a glance. J Cell Sci 2009;122:749-52. http://dx.doi.org/10.1242/jcs.037630.

[57] Ploegh HL. A lipid-based model for the creation of an escape hatch from the endoplasmic reticulum. Nature 2007;448:435-8. http://dx.doi.org/10.1038/ nature06004.

[58] Garay LA, Boundy-Mills KL, German JB. Accumulation of high-value lipids in single-cell microorganisms: a mechanistic approach and future perspectives.
J Agric Food Chem 2014;62:2709-27. http://dx.doi.org/10.1021/jf4042134.

[59] Hassan M, Blanc P, Granger L-M, Pareilleux A, Goma G. Lipid production by an unsaturated fatty acid auxotroph of the oleaginous yeast Apiotrichum curvatum grown in single-stage continuous culture. Appl Microbiol Biotechno 1993;40:483-8. http://dx.doi.org/10.1007/BF00175735.

[60] Meesters PAEP, Huijberts GNM, Eggink G. High-cell-density cultivation of the lipid accumulating yeast Cryptococcus curvatus using glycerol as a carbon source. Appl Microbiol Biotechnol 1996;45:575-9. http://dx.doi.org/10.1007/ s002530050731.

[61] Ykema A, Verbree EC, Nijkamp HJJ, Smit H. Isolation and characterization of fatty acid auxotrophs from the oleaginous yeast Apiotrichum curvatum. App Microbiol Biotechnol 1989;32:76-84. http://dx.doi.org/10.1007/BF00164826.

[62] Moreton RS. Modification of fatty acid composition of lipid accumulating yeasts with cyclopropene fatty acid desaturase inhibitors. Appl Microbiol Biotechnol 1985;22:41-5. http://dx.doi.org/10.1007/BF00252154.

[63] Dias JM, Alvim-Ferraz MCM, Almeida MF. Comparison of the performance of different homogeneous alkali catalysts during transesterification of waste and virgin oils and evaluation of biodiesel quality. Fuel 2008;87:3572-8. http:// dx.doi.org/10.1016/j.fuel.2008.06.014.

[64] Knothe G, Steidley KR. Kinematic viscosity of biodiesel fuel components and related compounds. Influence of compound structure and comparison to petrodiesel fuel components. Fuel 2005;84:1059-65. http://dx.doi.org/ 10.1016/j.fuel.2005.01.016.

[65] Suh HK, Lee CS. A review on atomization and exhaust emissions of a biodieselfueled compression ignition engine. Renew Sustain Energy Rev 2016;58: 1601-20. http://dx.doi.org/10.1016/j.rser.2015.12.329.

[66] Hoekman SK, Broch A, Robbins C, Ceniceros E, Natarajan M. Review of biodiesel composition, properties, and specifications. Renew Sustain Energy Rev 2012;16:143-69. http://dx.doi.org/10.1016/j.rser.2011.07.143.

[67] Ramírez-Verduzco LF, Rodríguez-Rodríguez JE, Jaramillo-Jacob ADR. Predicting cetane number, kinematic viscosity, density and higher heating value of biodiesel from its fatty acid methyl ester composition. Fuel 2012;91:102-11. http://dx.doi.org/10.1016/j.fuel.2011.06.070.

[68] Oliveira LE, Da Silva MLCP. Relationship between cetane number and calorific value of biodiesel from Tilapia visceral oil blends with mineral diesel. In: Int. Conf. Renew. Energies Power Qual; 2013.

[69] Gen Q Wang O Chi Z-M. Direct conversion of cassava starch into single cell oil by co-cultures of the oleaginous yeast Rhodosporidium toruloides and immobilized amylases-producing yeast Saccharomycopsis fibuligera. Renew Energy 2014;62:522-6. http://dx.doi.org/10.1016/j.renene.2013.08.016.

[70] Wang R, Wang J, Xu R, Fang Z, Liu A. Oil production by the oleaginous yeast Lipomyces starkeyi using diverse carbon sources. BioResources 2014;9: 7027-40. http://dx.doi.org/10.15376/biores.9.4.7027-7040.

71] Polburee P, Yongmanitchai W, Honda K, Ohashi T, Yoshida T, Fujiyama K, et al. Lipid production from biodiesel-derived crude glycerol by Rhodosporidium fluviale DMKU-RK253 using temperature shift with high cell density. Biochem Eng J 2016;112:208-18. http://dx.doi.org/10.1016/j.bej.2016.04.024.

[72] Huang XF, Liu JN, Lu LJ, Peng KM, Yang GX, Liu JN. Culture strategies for lipid production using acetic acid as sole carbon source by Rhodosporidium toruloides. Bioresour Technol 2016;206:141-9. http://dx.doi.org/10.1016 j.biortech.2016.01.073.

[73] Luque L, Orr VCA, Chen S, Westerhof R, Oudenhoven S, Rossum G van, et al. Lipid accumulation from pinewood pyrolysates by Rhodosporidium diobovatum and Chlorella vulgaris for biodiesel production. Bioresour Technol 2016;214:660-9. http://dx.doi.org/10.1016/j.biortech.2016.05.030.

[74] Poontawee R, Yongmanitchai W, Limtong S. Efficient oleaginous yeasts for lipid production from lignocellulosic sugars and effects of lignocellulose degradation compounds on growth and lipid production. Process Biochem 2017;53:44-60. http://dx.doi.org/10.1016/j.procbio.2016.11.013.

[75] Uprety BK, Dalli SS, Rakshit SK. Bioconversion of crude glycerol to microbia lipid using a robust oleaginous yeast Rhodosporidium toruloides ATCC 10788 capable of growing in the presence of impurities. Energy Convers Manag 2017;135:117-28. http://dx.doi.org/10.1016/j.enconman.2016.12.071. 